\title{
Identification and molecular characterization of a
}

\section{Chlamydomonas reinhardtii mutant that shows a light \\ intensity dependent progressive chlorophyll deficiency}

\section{[version 1; peer review: 2 approved]}

\author{
Phillip B Grovenstein1', Darryel A Wilson1, Kathryn D Lankford1', Kelsey A Gaston 1,2, \\ Surangi Perera1,3, Mautusi Mitra (D1) \\ ${ }^{1}$ Department of Biology, University of West Georgia, Carrollton GA, 30118, USA \\ ${ }^{2}$ Current address: Pediatric Infectious Diseases, Emory-Children's Center, Atlanta GA, 30322, USA \\ ${ }^{3}$ Current address: Joseph J. Zilber School of Public Health, University of Wisconsin-Milwaukee, Milwaukee WI, 53204, USA
}

V1 First published: 19 Jun 2013, 2:142
https://doi.org/10.12688/f1000research.2-142.v1

Latest published: 29 Jul 2013, 2:142

https://doi.org/10.12688/f1000research.2-142.v2

\begin{abstract}
The green micro-alga Chlamydomonas reinhardtii is an elegant model organism to study all aspects of oxygenic photosynthesis. Chlorophyll (Chl) and heme are major tetrapyrroles that play an essential role in energy metabolism in photosynthetic organisms. These tetrapyrroles are synthesized via a common branched pathway that involves mainly nuclear encoded enzymes. One of the enzymes in the pathway is $\mathrm{Mg}$ chelatase (MgChel) which inserts $\mathrm{Mg}^{2+}$ into protoporphyrin IX (PPIX, proto) to form Magnesium-protoporphyrin IX (MgPPIX, Mgproto), the first biosynthetic intermediate in the Chl branch. The GUN4 (genomes uncoupled 4) protein is not essential for the MgChel activity but has been shown to significantly stimulate its activity. We have isolated a light sensitive mutant, 6F14, by random DNA insertional mutagenesis. 6F14 cannot tolerate light intensities higher than 90-100 $\mu \mathrm{mol}$ photons $\mathrm{m}^{-2} \mathrm{~s}^{-1}$. It shows a light intensity dependent progressive photobleaching. 6F14 is incapable of photo-autotrophic growth under light intensity higher than $100 \mu \mathrm{mol}$ photons $\mathrm{m}^{-2} \mathrm{~s}^{-1}$. PCR based analyses show that in $6 F 14$ the insertion of the plasmid outside the GUN4 locus has resulted in a genetic rearrangement of the GUN4 gene and possible deletions in the genomic region flanking the GUN4 gene. Our gun4 mutant has a Chl content very similar to that in the wild type in the dark and is very sensitive to fluctuations in the light intensity in the environment unlike the earlier identified Chlamydomonas gun4 mutant. Complementation with a functional copy of the GUN4 gene restored light tolerance, $\mathrm{Chl}$ biosynthesis and photo-autotrophic growth under high light intensities in 6F14. 6F14 is the second gun4 mutant to be identified in C. reinhardtii. Additionally, we show that our
\end{abstract}

\section{Open Peer Review}

Approval Status

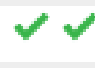

1 2

version 2

(update)

29 Jul 2013

version 1

19 Jun 2013

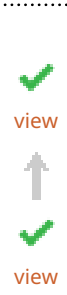

\section{Kittisak Yokthongwattana (ID), Mahidol \\ University, Bangkok, Thailand \\ 2. EonSeon Jin, Hanyang University, Seoul, \\ South Korea}

Any reports and responses or comments on the article can be found at the end of the article. 
two gun4 complements over-express the GUN4 protein and show a higher Chl content per cell compared to that in the wild type strain.

\section{Keywords}

Chlamydomonas reinhardtii, algae, Chlorophyll, Gun4, 6F14, light

sensitivity

\section{Associated Research Article}

Grovenstein PB, Wilson DA, Lennox CG et al. » Identification and molecular characterization of a novel Chlamydomonas reinhardtii mutant defective in chlorophyll biosynthesis, F1000Research 2013, 2:138 (https://doi.org/10.12688/f1000research.2-138.v2)

Corresponding author: Mautusi Mitra (mmitra@westga.edu)

Competing interests: No competing interests were disclosed.

Grant information: This project was supported by several grants awarded to Dr. Mautusi Mitra. These are: the start-up grant of the University of West Georgia (UWG), the Faculty Research Grant by the UWG College of Science and Mathematics, the Internal Development Grant by the UWG office of Research and Sponsored Project, the Research Incentive grant by the UWG College of Science and Mathematics, the UWG Student Research Assistance Program (SRAP) grant and the UWise-BOR-STEM II grant from UWG. The funders had no role in study design, data collection and analysis, decision to publish, or preparation of the manuscript.

Copyright: $\odot 2013$ Grovenstein PB et al. This is an open access article distributed under the terms of the Creative Commons Attribution License, which permits unrestricted use, distribution, and reproduction in any medium, provided the original work is properly cited. Data associated with the article are available under the terms of the Creative Commons Zero "No rights reserved" data waiver (CC0 1.0 Public domain dedication).

How to cite this article: Grovenstein PB, Wilson DA, Lankford KD et al. Identification and molecular characterization of a Chlamydomonas reinhardtii mutant that shows a light intensity dependent progressive chlorophyll deficiency [version 1; peer review: 2 approved] F1000Research 2013, 2:142 https://doi.org/10.12688/f1000research.2-142.v1

First published: 19 Jun 2013, 2:142 https://doi.org/10.12688/f1000research.2-142.v1 


\section{Introduction}

Chlamydomonas reinhardtii is a green micro-alga that can grow heterotrophically in the dark by metabolizing exogenous acetate. It possesses a photosynthetic apparatus very similar to higher plants, has a short and simple haplontic life cycle, can synthesize Chl both light dependently and light independently (unlike most angiosperms) and its genome has been sequenced ${ }^{1}$. In addition, well developed molecular tools exist for genetic manipulations of its genome. All these traits make this alga an elegant system for dissecting photosynthesis and chloroplast biogenesis ${ }^{2,3}$.

Chl, heme, siroheme, cobalamin, heme $d 1$ and factor F430 are major tetrapyrroles that are involved in wide variety of essential life processes in all living organisms. Chl and heme are synthesized via a common branched pathway ${ }^{4,5}$ (outlined in Figure 1). Photosynthetic eukaryotes synthesize 5-aminolevulinic acid (ALA) from glutamine (Glu) bound to tRNA ${ }^{\text {Glu }}$ through the C5 pathway consisting of two steps catalyzed by glutamyl-tRNA reductase and glutamate-1-semialdehyde aminotransferase ${ }^{4,5}$. ALA is subsequently converted in six steps to PPIX, the last common precursor for both $\mathrm{Chl}$ and heme biosynthesis ${ }^{4,5}$. Insertion of $\mathrm{Fe}^{2+}$ into PPIX by ferrochelatase (FeChel) leads to heme. Insertion of $\mathrm{Mg}^{2+}$ in PPIX by the heterotrimeric $\mathrm{MgCh}$ (comprised of three subunits: CHLD, $\mathrm{CHLH}$ and $\mathrm{CHLI}^{6}$ ) leads to MgPPIX, the first biosynthetic intermediate in the $\mathrm{Chl}$ branch $^{6}$. MgPPIX is converted to Pchlide via three enzymatic steps. The reduction of Pchlide to form chlorophyllide (Chlide) can occur by two different mechanisms. One mechanism is

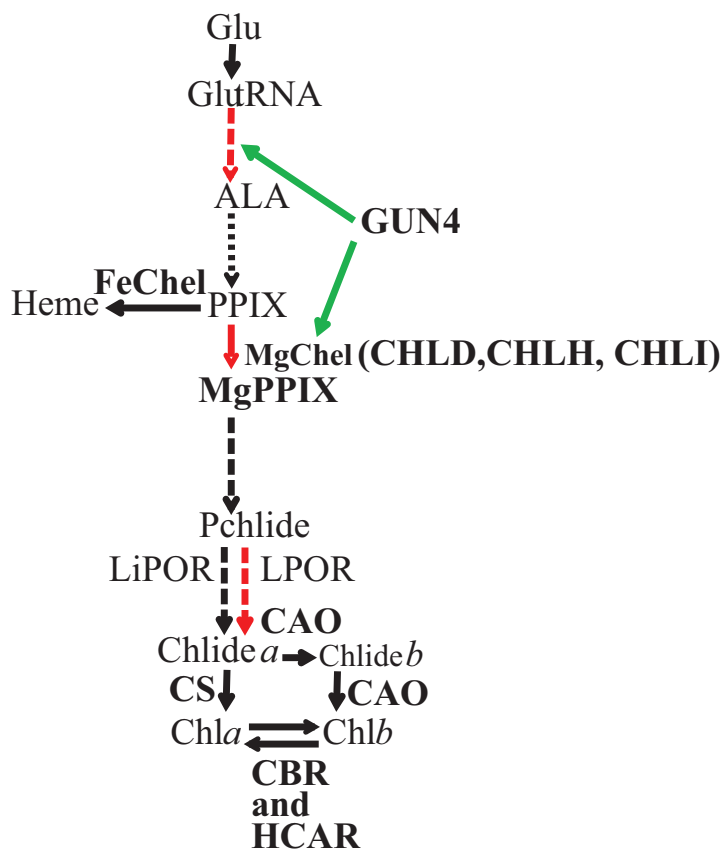

Figure 1. A simplified tetrapyrrole biosynthetic pathway. Light regulated steps are in red. Dashed arrows denote multiple enzymatic steps and green arrows point to steps that are positively regulated by the GUN4 protein, respectively. Tetrapyrrole intermediates and enzymes are shown in black and bold black type, respectively. Readers are advised to look in the text for full names of tetrapyrrole intermediates and enzymes, which are abbreviated in this figure. catalyzed by the strictly light dependent enzyme NADPH:Pchlide oxidoreductase (LPOR) and occurs in all photosynthetic organisms; it is the only mechanism of $\mathrm{Chl}$ formation in angiosperms ${ }^{7-10}$. The second mechanism is catalyzed by the light independent NADPH:Pchlide oxidoreductase (LiPOR) and is present in anoxygenic bacteria, alga, ferns and gymnosperms ${ }^{11-20}$. The Chlide $a$ undergoes a phytylation reaction, catalyzed by Chl synthase (CS), resulting in the formation of $\mathrm{Chl} a$. In vascular plants and green algae a portion of the Chlide $a$ is converted to Chlide $b$ by Chlide $a$ oxygenase (CAO) prior to phytylation ${ }^{21-24}$. Chl $a$ is converted to $\mathrm{Chl}$ $b$ by CAO via formation of 7-hydroxymethyl chlorophyll $a$ (HCA) and $\mathrm{Chl} b$ can be converted back to Chl $a$ via HCA by chlorophyll $b$ reductase (CBR) and 7-hydroxymethyl chlorophyll $a$ reductase $(\mathrm{HCAR})^{25}$. This inter-conversion of Chl $a$ and $\mathrm{Chl} b$, referred to as the "chlorophyll cycle", plays an important role in greening, acclimation to light and senescence ${ }^{25}$.

Stringent control of tetrapyrrole biosynthesis is especially essential for oxygenic photosynthetic organisms that are often prone to oxidative stress. Free $\mathrm{Chl}$, heme and their immediate precursors are highly photo-toxic molecules and generate reactive oxygen species (ROS) under aerobic conditions ${ }^{26}$. Hence most of the cellular Chls are usually bound to the light harvesting complex (LHC) and other photosystem (PS) proteins. Chl is made in the plastid. Most of these Chl binding proteins and enzymes of the tetrapyrroles biosynthetic pathways are encoded by the nuclear genes ${ }^{5}$. Hence a tight coordination of biosynthesis of $\mathrm{Chl}$ with its apoprotein is necessary ${ }^{27}$. $\mathrm{Chl}$ and heme biosynthesis in plants is under transcriptional, translational and post-translational control at multi level and is accomplished by a complex regulatory network among the chloroplasts, mitochondria and nucleus, that is not well understood ${ }^{28-30}$.

One of the major research interests of our laboratory is to identify components that play a role in the regulation of Chl biosynthesis under different irradiance conditions. We have generated a random DNA insertional Chlamydomonas mutant library and have screened it to isolate twenty one mutants that are either defective in Chl biosynthesis and/or are incapable of photo-autotrophic growth under different irradiance conditions. One of the isolated mutants (6F14) is a light sensitive mutant which shows a light intensity dependent progressive photo-bleaching and is incapable of photosynthesis under low light intensities $\left(90-100 \mu \mathrm{mol} \mathrm{m}^{-2} \mathrm{~s}^{-1}\right)$. Molecular analyses revealed that $6 F 14$ is defective in the GUN4 (genome uncoupled 4) gene which codes for a protein that stimulates $\mathrm{MgChel}$ activity. $6 F 14$ is the second gun 4 mutant to be identified in Chlamydomonas ${ }^{31}$. Transformation of $6 F 14$ with a functional copy of the GUN4 gene restored the wild type phenotype. Western analyses show that the two isolated gun4 complements are over-expressing the GUN4 protein. Chl analyses show that these gun 4 complements have 50-60\% more Chl than that of the wild type strain. In this study, we present our molecular data on the identification of the mutation locus in $6 F 14$ and its complementation.

\section{Materials and methods}

Algal media and cultures

Chlamydomonas strains 4A+ (a gift from Dr. Krishna Niyogi (UC, Berkeley), gun4 and gun4 complements (both generated by our laboratory) were grown either in Tris-Acetate Phosphate 
(TAP) heterotrophic media or in Sueoka's High Salt (HS) photoautotrophic media. TAP and HS liquid media and agar plates were prepared in the lab using reagents from Fisher Scientific (Pittsburgh, PA) according to the protocol given in Gorman and Levine $(1965)^{32}$ and Sueoka $(1960)^{33}$, respectively. The 4A+ strain and gun4 complements were maintained on TAP agar plates and TAP + zeocin (Sigma, St. Louis, MO) plates, respectively under dim light intensities $\left(10-15 \mu \mathrm{mol}\right.$ photons $\left.\mathrm{m}^{-2} \mathrm{~s}^{-1}\right)$ at $25^{\circ} \mathrm{C}$. The final zeocin concentration was $15 \mu \mathrm{g} / \mathrm{ml}$. The gun4 mutant (6F14) was maintained in the dim light or in the dark on TAP $1.5 \%$ agar plates containing $10 \mu \mathrm{g} / \mathrm{ml}$ of paromomycin (Sigma, St. Louis, MO). Liquid algal cultures used for RNA and genomic DNA extractions and protein analyses were grown in $100 \mathrm{ml}$ flasks on the New Brunswick Scientific Excella E5 platform shaker (Enfield, CT) in TAP media at $150 \mathrm{rpm}$ in the dim light.

\section{Generation of the $6 F 14$ mutant}

The purified pBC1plasmid from the DH5 $\alpha$ Escherichia coli- $p B C 1$ clone (obtained from Dr. Krishna Niyogi's laboratory at UC, Berkeley) was used for random DNA insertional mutagenesis. This plasmid contains two antibiotic resistance genes: APHVIII and $A m p^{R}$ (Figure 2). APHVIII confers resistance against the antibiotic paromomycin and was used as a selection marker for screening of Chlamydomonas transformants. $A m p^{R}$ was used as a selection marker for screening of $E$. coli clones harboring the $\mathrm{pBC} 1$ plasmid. E. coli was grown in 11 of Luria Bertani (LB) broth containing $1 \%$ tryptone, $0.5 \%$ of yeast extract, $1 \% \mathrm{NaCl}$ and ampicillin (final concentration of ampicillin: $100 \mu \mathrm{g} / \mathrm{ml}$ ). LB media was prepared in the laboratory using reagents purchased from Fisher (Pittsburgh, PA). Ampicillin was purchased from Fisher (Pittsburgh, PA). The culture was incubated at $37^{\circ} \mathrm{C}$ overnight. Plasmid purification from $E$. coli cells was facilitated by a Qiagen plasmid mega kit according to the protocol given in the technical manual (Qiagen, Valencia, CA). Once purified from $E$. coli, the circular $\mathrm{pBC} 1$ vector was linearized with the restriction enzyme KpnI (NEB, Beverly, MA) according to the protocol given in the technical manual. The linearized DNA was purified using a QIAEX II gel extraction kit (Qiagen, Valencia, CA) according to the protocol given in the technical manual. All agarose DNA gel electrophoresis was visualized by BioRad Molecular Imager Gel Doc XR+ (BioRad, Hercules, CA). Transformation of parental strain $4 \mathrm{~A}+$ by the linearized $\mathrm{pBC} 1$ vector was performed utilizing the glass bead transformation technique described by Kindle et al. (1989) $)^{34}$ and Dent et al. (2005) ${ }^{2}$.
Transformants were plated onto fresh TAP agar plates containing $10 \mu \mathrm{g} / \mathrm{ml}$ paromomycin (TAP+P) in the dark. Single colonies of mutants were picked and transferred onto fresh $\mathrm{TAP}+\mathrm{P}$ plates using a numbered grid layout. Screening of photosynthetic and pigment deficient mutants was done by visual inspection and monitoring of growth under different light intensities in heterotrophic, mixotrophic and photo-autotrophic conditions ${ }^{2}$.

\section{Genomic DNA and RNA extraction}

$4 \mathrm{~A}+$, gun4 complements and gun4 were grown in TAP liquid media in the dim light to a cell density of about $5 \times 10^{6}$ cells $/ \mathrm{ml}$ of the culture. Genomic DNA was purified using a phenol-chloroform extraction method ${ }^{35}$. RNA extraction was facilitated by TRIzol reagent from Invitrogen (Carlsbad, CA) following the protocol in the technical manual. DNA and RNA concentrations were measured using a Nanodrop 1000 spectrophotometer from Thermo Fisher Scientific (Wilmington, DE). DNase treatment was performed using Ambion's TURBO DNA-free kit from Invitrogen (Carlsbad, CA) following the protocol in the technical manual to remove genomic DNA from the RNA preparation. Generation of cDNA was performed using Life Technologies Superscript III First-Strand Synthesis System from Invitrogen (Carlsbad, CA) following the protocol in the technical manual.

\section{Thermal Asymmetric InterLaced PCR}

TAIL (Thermal Asymmetric InterLaced) PCR was implemented, following the protocol of Dent et al. $(2005)^{2}$. HotStar Taq Plus DNA polymerase kit reagents (Qiagen, Valencia, CA) were used for PCR. The PCR reaction mixture consisted of $1 \times$ PCR buffer, $200 \mu \mathrm{M}$ of each dNTP, $1 \times$ Q-solution, 2.5 units of HotStar Taq Plus DNA polymerase, 60 pmoles of the random degenerate primer RD1 and $5 \mathrm{pmol}$ of the APHVIII specific primer. Primers were ordered from IDT (Skokie, IL; Table 1). Degenerate primer RD1 has an average $T_{\mathrm{m}}$ of $51^{\circ} \mathrm{C}$ while the three $A P H V I I I$ specific primers used had $T_{\mathrm{m}}$ ranging from $58^{\circ} \mathrm{C}$ to $64^{\circ} \mathrm{C}$. PCR cycling programs were created using the program given in Dent et al. (2005) ${ }^{2}$. TAIL1 PCR product was diluted 10 -fold and $2 \mu \mathrm{l}$ of the diluted TAIL1 PCR product was used for TAIL2 PCR reactions. The TAIL2 PCR product was gel purified using a QIAEX II gel extraction kit (Qiagen, Valencia, CA) according to the protocol given in the technical manual. Purified TAIL2 PCR product was sequenced at the UC, Berkeley DNA Sequencing Facility (Berkeley, CA). All primer sequences are shown in Table 1.

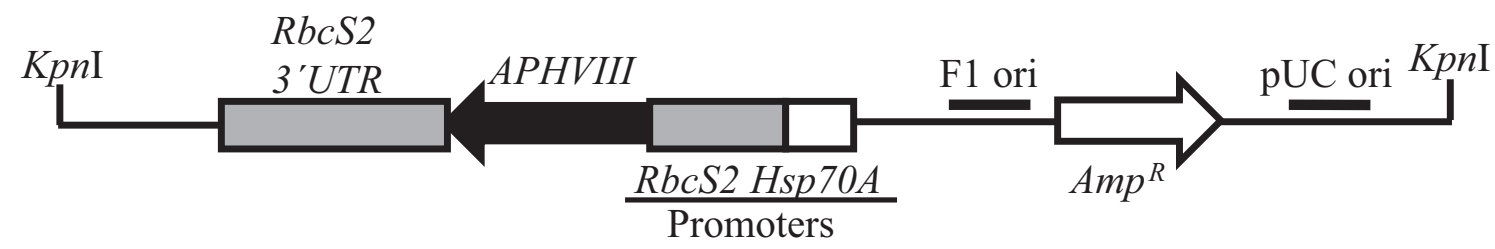

Figure 2. Linearized pBC1 plasmid used for random insertional mutagenesis. The cleavage site of Kpn1 restriction enzyme, used for linearization of the vector is shown. APHVIII is under the control of combo promoters which consist of the promoter of the gene encoding the small subunit of Rubisco (RbcS2) and the gene encoding the heat shock protein 70A (Hsp70A). pBC1 is a phagemid and its F1 origin (F1 ori) and pUC origin (pUC ori) are shown. The size of the plasmid is $4763 \mathrm{bp}$ 
Genomic and reverse transcription PCR

Primers were designed based on genomic DNA sequences available in the Chlamydomonas genome database in Phytozome. Amplifications of genomic DNA and cDNA were executed using the MJ Research PTC-200 Peltier Thermal Cycler (Watertown, MA). HotStar Taq Plus DNA polymerase kit (Qiagen, Valencia, CA) was used for PCR following the cycling conditions given in the Qiagen protocol booklet. Annealing temperature was between 55 and $60^{\circ} \mathrm{C}$ depending on the $T_{\mathrm{m}}$ of the primers. Extension time was varied according to the size of the PCR product amplified. Final extension was set at $72^{\circ} \mathrm{C}$ for ten minutes. All genomic and reverse transcription PCR products were amplified for a total of thirty-five cycles. A 50-150 ng sample of genomic DNA or cDNA were used for PCR reactions. For semi-quantitative RT-PCR reactions, $3 \mu \mathrm{g}$ of total RNA was converted into cDNA and then $150 \mathrm{ng}$ of cDNA templates were used for RT-PCR. Sequences of primers used for genomic and RT-PCR are shown in Table 2-Table 4.

Cloning of the GUN4 gene in the pDBle vector

The pDBle vector (obtained from Dr. Saul Purton, University College London, UK) was double-digested with restriction enzymes EcoRI and NdeI (NEB, Beverly, MA) according to the protocol given in the technical manual. The GUN4 gene was amplified using primers given in Table 5. Ligation of the double digested (NdeI and EcoRI digested) GUN4 gene and the NdeI/EcoRI double-digested pDBle vector was done using the T4 ligase and $1 \mathrm{mM}$ ATP (NEB, Beverly, MA). Chemically competent $\left(\mathrm{CaCl}_{2}\right.$ treated) $E$. coli cells were used for transformation. After transformation, E. coli cells were plated on LB+ampicillin (final concentration of ampicillin: $100 \mu \mathrm{g} / \mathrm{ml}$ ) plates and incubated at $37^{\circ} \mathrm{C}$ overnight. Single colonies were picked the next day and plasmids were isolated from these clones. Isolated plasmids were double-digested with EcoRI and NdeI to verify the cloning of the GUN4 gene. The GUN4-pDBle construct from the selected clone was sequenced by the UC, Berkeley DNA Sequencing Facility (Berkeley, CA). Chromas Lite (http://technelysium. com.au/) and BLAST were used to analyze DNA sequences.

Generation and screening of gun4 complements

Complementation of the gun4 was performed utilizing the glass bead transformation technique described by Kindle et al. $1989^{34} .2 \mu \mathrm{g}$ of the linearized GUN4-pDBle was used to complement $6 F 14$. Transformed cells were plated onto fresh TAP

Table 1. List of primers used for TAIL (Thermal Asymmetric InterLaced) PCR, verification of TAIL PCR product and DNA sequencing. These primers were used to generate the data in Figure 7 and Figure 8.

\begin{tabular}{|c|c|c|}
\hline Primer name & Sequence of primer & Location \\
\hline RD1 & 5'-WNG GGS CNG CWT TT-3' & Degenerate primer \\
\hline $7 \mathrm{~F}$ & $5^{\prime}$-ACG GAG GAT CGT TAC AAC CAA CAA-3' & APHVIII 3' UTR \\
\hline $2 \mathrm{R}$ & $5^{\prime}-\mathrm{CTC}$ AAG TGC TGA AGC GGT AGC TTA-3' & APHVIII 3 UTR \\
\hline $3 R$ & $5^{\prime}$-TCT TCT GAG GGA CCT GAT GGT GTT-3' & APHVIII 3' UTR \\
\hline $4 \mathrm{R}$ & $5^{\prime}$-GGG CGG TAT CGG AGG AAA AGC TG-3' & APHVIII 3' UTR \\
\hline
\end{tabular}

Table 2. List of GUN4 specific primers. These primers were used for GUN4 (Cre05.g246800) genomic DNA PCR on $6 F 14$ and $4 \mathrm{~A}+$ and also for DNA sequencing to generate the data in Figure 8 and Figure 9.

\begin{tabular}{|c|c|c|}
\hline Primer name & Sequence of primer & Location \\
\hline $2 \mathrm{R}$ & 5'AGTGTGTGTTTGGGCCAGCATTT-3' & Exon1 \\
\hline $3 F$ & 5'-TGTGGAGAAGAAGAAGTCCGGCAA-3' & Exon1 \\
\hline $3 R$ & 5'-TTGCCGGACTTCTTCTTCTCCACA-3' & Exon1 \\
\hline $14 \mathrm{~F}$ & 5'-GATCCGCAGCCTCACGAG-3' & Exon1 \\
\hline $14 \mathrm{R}$ & 5'-CCTCGTGAGGCTGCGGATC-3' & Exon1 \\
\hline $7 \mathrm{~F}$ & 5'-ACAACCCTTGACTTGCGACTCTGT-3' & Exon2 \\
\hline 7R & 5'-ACAGAGTCGCAAGTCAAGGGTTGT-3' & Exon2 \\
\hline $8 \mathrm{~F}$ & 5'-ACCGCATCTTGCAAAGATTGCACC-3' & Exon2 \\
\hline $8 \mathrm{R}$ & 5'-GGTGCAATCTTTGCAAGATGCGGT-3' & Exon2 \\
\hline $10 R$ & 5'AGTCTTACACAGGCATACTGCAGCG-3' & Exon2 \\
\hline $11 \mathrm{R}$ & 5'-CTCTTTCAGTCTTACACAGGCATACTGC-3' & Exon2 \\
\hline $12 \mathrm{~F}$ & 5'-AGCCGGACTGTTGCGTAATGTGAT-3’' & Exon2 \\
\hline $12 \mathrm{R}$ & 5'-ATCACATTACGCAACAGTCCGGCT-3' & Exon2 \\
\hline
\end{tabular}


Table 3. List of primers used for checking the genomic region upstream of GUN4 (Cre05. g246800) and HYP2 [g5195] gene. These primers were used to generate the data in Figure 10 and Figure 11.

\begin{tabular}{lll} 
Primer name & Sequence of primer & Location \\
\hline ACF6 & 5'-ACATAGCAGCGAGACACACCACAT-3' & Upstream of GUN4 region \\
\hline ACF7 & 5'-AACAAATCCGCGAACGCCACTATG-3' & Upstream of GUN4 region \\
\hline ACR7 & 5'-CATAGTGGCGTTCGCGGATTTGTT-3' & Upstream of GUN4 region \\
\hline ACF11 & 5'-GCAACCGGTGTTTGGGCGTATTAT-3' & Upstream of GUN4 region \\
\hline ACR11 & 5'-ATAATACGCCCAAACACCGGTTGC-3' & Upstream of GUN4 region \\
\hline H3F & 5'-TCCCATGGTATCCCGAGCTTGAAA-3' & 3' end of HYP2 \\
\hline H4F & 5'-TGAGGAAACTGGACTTGGCTGAGT-3' & 3' end of HYP2 \\
H5F & 5'-TACCAGCAGCATCTAAGCACCACA-3' & 3' end of HYP2 \\
H6R & 5'-TATTCTAATGCAGCACGGCAAGGC-3' & 3' end of HYP2
\end{tabular}

\begin{abstract}
Table 4. List of primers used for transcript analysis of GUN4 and GUN4 neighboring genes in $6 \mathbf{F 1 4}$. These primers were used to generate the data in Figure 12. The gene loci numbers in Phytozome for the three neighboring genes of GUN4 on chromosome 5 and the control actin gene on chromosome 13 are: HYP1 [Cre05.g246750], HYP2 [g5195] and SOXE [Cre05.g246900] and Actin (Cre13.g603700), respectively.
\end{abstract}

\begin{tabular}{|lll|}
\hline Primer name & Sequence of primer & Purpose \\
\hline F2 & 5'-ACGACACCACCTTCAACTCCATCA-3' & Actin \\
\hline R2 & 5'-TTAGAAGCACTTCCGGTGCACGAT-3' & Actin \\
\hline NupF4 & 5'-TGTATGAACTCTGAGCAGGCGACA-3' & HYP1 \\
\hline Nup98R2 & 5'-CCTGCCGTATGTCGTGCACAAAC-3' & HYP1 \\
\hline 3F & 5'-TGTGGAGAAGAAGAAGTCCGGCAA-3' & GUN4 \\
\hline 8R & 5'-GGTGCAATCTTTGCAAGATGCGGT-3' & GUN4 \\
\hline HypF2 & 5'-TTCCTGGCTACTGCCGTATTCGCA-3' & HYP2 \\
\hline H6F & 5'-GCCTTGCCGTGCTGCATTAGAATA-3' & HYP2 \\
\hline PB120 & 5'-GCACGGATGGCAAGTACATG-3' & SOXE \\
\hline PB121 & 5'-CTACTTCACTGCCCTGGAGTTT-3' & SOXE \\
\hline
\end{tabular}

Table 5. List of primers used for cloning and complement testing. These primers were used in the experiments that generated the data in Figure 13 and Figure 16 and were also used for GUN4 gene amplification for cloning.

\begin{tabular}{|c|c|c|}
\hline Primer name & Sequence of primer & Purpose \\
\hline GUN4F1 & 5'-GGAATTCCATATGCTGGCCCAAACACACACT-3' & Amplification of GUN4 for cloning \\
\hline GUN4R1 & 5'-CCGGAATTCTTAGAACAGCGACTGTGTCCGCC-3' & $\begin{array}{l}\text { Amplification of GUN4 for cloning } \\
\text { and for complement testing }\end{array}$ \\
\hline PsaDF1 & 5'-CCACTGCTACTCACAACAAGCCCA-3' & Complement testing \\
\hline
\end{tabular}

plates containing $15 \mu \mathrm{g} / \mathrm{ml}$ zeocin $(\mathrm{Z})$ and placed in the dark at $25^{\circ} \mathrm{C}$. Single colonies were picked and transferred onto fresh $\mathrm{TAP}+\mathrm{Z}$ plates using a numbered grid template for screening of potential gun4 complements. Screening of gun4 complements was done by monitoring the Chl content and growth of complement strains either on TAP or HS plates under medium light ( $300 \mu \mathrm{mol}$ photons $\mathrm{m}^{-2} \mathrm{~s}^{-1}$ ) in the presence or absence of antibiotics zeocin and paromomycin.
Cellular protein analysis

Chlamydomonas cells from different strains grown in TAP in the dim light were harvested, washed twice with fresh medium and resuspended in TEN buffer $(10 \mathrm{mM}$ Tris- $\mathrm{HCl}, 10 \mathrm{mM}$ EDTA and $150 \mathrm{mM} \mathrm{NaCl}$; $\mathrm{pH}$ 8). Gel lanes were loaded with an equal amount of Chl (4 $\mu \mathrm{g}$ Chl). Resuspended cell suspension was mixed in a 1:1 ratio with the sample solubilization buffer SDS-urea buffer (150 mM Tris-HCl, pH 6.8; 7\% w/v SDS; $10 \%$ w/v glycerol; $2 \mathrm{M}$ 
urea; bromophenol blue and $10 \% \beta$-mercaptoethanol) and were incubated at room temperature for about thirty minutes, with intermittent vortexing. The sample solubilization buffer was prepared according to the protocol of Smith et al. (1990) ${ }^{36}$ using reagents from Fisher (Pittsburgh, PA). After incubation, the solubilized protein samples were vortexed and spun at a maximum speed of $20,000 \mathrm{~g}$ in a $1.5 \mathrm{ml}$ eppendorf tube (USA Scientific, Ocala, FL) for five minutes at $4^{\circ} \mathrm{C}$. The soluble fraction was loaded on a "any $\mathrm{kD}^{\mathrm{TM}}$ Mini-PROTEAN ${ }^{\circledR}$ TGX ${ }^{\mathrm{TM}}$ Precast Gel" (BioRad, Hercules, CA) and SDS-PAGE analysis was performed according to Laemmli (1970) ${ }^{37}$ using a Page Ruler prestained molecular weight protein ladder (Fermentas, Glen Burnie, Maryland) at a constant current of $80 \mathrm{~V}$ for 2 hours. Gels were stained with colloidal Coomassie Gel Code blue stain reagent (Thermo Fisher Scientific, Rockford, IL) for protein visualization.

\section{Western analysis}

Electrophoretic transfer of the SDS-PAGE resolved proteins onto an Immobilon P-PVDF membrane (Millipore, Billerica, MA) was carried out for 2 hours at a constant current of $400 \mathrm{~mA}$ in the transfer buffer (25 mM Tris, $192 \mathrm{mM}$ glycine and $20 \%$ methanol). The GUN4 polyclonal antibody was raised in rabbit against the full length Chlamydomonas GUN4 mature protein that lacks the first 45 amino acids corresponding to the predicted chloroplast transit peptide ${ }^{31}$. This antibody was generated by Dr. Roberto Bassi's laboratory (University of Verona, Italy) and was provided to us by Dr. Krishna Niyogi (UC, Berkeley). GUN4 primary antibodies were diluted to a ratio of 1:1000 before being used as a primary probe. The secondary antibodies used for Western blotting were conjugated to horseradish peroxidase (Pierce protein research product, Thermo Fisher Scientific, Rockford, IL) and diluted to a ratio of 1:20,000 with the antibody buffer. Western blots were developed by using the Supersignal West Pico chemiluminescent substrate kit (Pierce protein research product, Thermo Fisher Scientific, Rockford, IL).

\section{Cell counts and chlorophyll extraction}

Cell density (number of cells per $\mathrm{ml}$ of the culture) was calculated by counting the cells using a Neubauer ultraplane hemacytometer (Hausser Scientific, Horsham, PA). Pigments from intact cells were extracted in $80 \%$ acetone and cell debris was removed by centrifugation at $10,000 \mathrm{~g}$ for 5 minutes. The absorbance of the supernatant was measured with a Beckman Coulter DU 730 Life Science UV/Vis spectrophotometer (Brea, CA). Chl $a$ and $b$ concentrations were determined by Arnon (1949) ${ }^{38}$ equations, with corrections as described by Melis et al. $(1987)^{39}$.

\section{Results}

Generation and identification of the mutant $6 F 14$

Mutant $6 F 14$ was generated by random insertional mutagenesis of the $C$. reinhardtii wild type strain $4 \mathrm{~A}+(137 \mathrm{c}$ genetic background). $6 F 14$ was identified as a slightly $\mathrm{Chl}$ deficient paromomycin resistant mutant on TAP $+\mathrm{P}$ plate in the dark (Figure 3).

\section{Growth analyses of 6F14}

Growth analyses in heterotrophic and photo-autotrophic liquid media revealed that $6 F 14$ is light sensitive and shows progressive photo-bleaching with increase in light intensities (Figure 4 and Figure 5). In mixotrophic conditions under $10-15 \mu \mathrm{mol}$ photons $\mathrm{m}^{-2} \mathrm{~s}^{-1}$, 6 F 14 possesses $58 \%$ less $\mathrm{Chl} /$ cell than $4 \mathrm{~A}+$. At $40-50 \mu \mathrm{mol}$ photons $\mathrm{m}^{-2} \mathrm{~s}^{-1}, 6 \mathrm{~F} 14$ has $72 \%$ less $\mathrm{Chl} /$ cell than the wild type. At 75-80 $\mu$ mol photons $\mathrm{m}^{-2} \mathrm{~s}^{-1}, 6 F 14$ possesses $99 \%$ less Chl/cell than the wild type. At $75-80 \mu \mathrm{mol}$ photons $\mathrm{m}^{-2} \mathrm{~s}^{-1}, 6$ F14 starts to photobleach and turns yellow; it dies at light intensities 100-120 $\mu \mathrm{mol}$ photons $\mathrm{m}^{-2} \mathrm{~s}^{-1}$ in TAP (Figure 4).

Figure 5 shows photo-autotrophic cultures of $6 F 14$ and $4 \mathrm{~A}+$. 6 F14 has the ability to grow photo-autotrophically in HS media in dim light $\left(10-15 \mu \mathrm{mol}\right.$ of photons $\left.\mathrm{m}^{-2} \mathrm{~s}^{-1}\right)$. However, the mutant grows extremely slowly in comparison to the wild type. When grown at $10-15 \mu$ mol photons $\mathrm{m}^{-2} \mathrm{~s}^{-1}$ in HS media, 6 F 14 possesses $60 \%$ less $\mathrm{Chl} /$ cell than the wild type. At $40-50 \mu \mathrm{mol}$ photons $\mathrm{m}^{-2} \mathrm{~s}^{-1}$ in HS media, $6 F 14$ has $79 \%$ less $\mathrm{Chl} /$ cell than $4 \mathrm{~A}+$, and at $75-80 \mu \mathrm{mol}$ photons $\mathrm{m}^{-2} \mathrm{~s}^{-1}$ in $\mathrm{HS}$ media, $6 F 14$ possesses $83 \%$ less $\mathrm{Chl} /$ cell than the wild type. At 100-120 $\mu \mathrm{mol}$ photons $\mathrm{m}^{-2} \mathrm{~s}^{-1}$ in HS media, $6 F 14$ fails to survive (Figure 5).

Figure 6 demonstrates that when dim light adapted $6 F 14$ was shifted to $40-50 \mu \mathrm{mol}$ photons $\mathrm{m}^{-2} \mathrm{~s}^{-1}$ there was no significant change in $\mathrm{Chl} /$ cell content (Figure 4). Dark adapted $6 F 14$ showed a $50 \%$
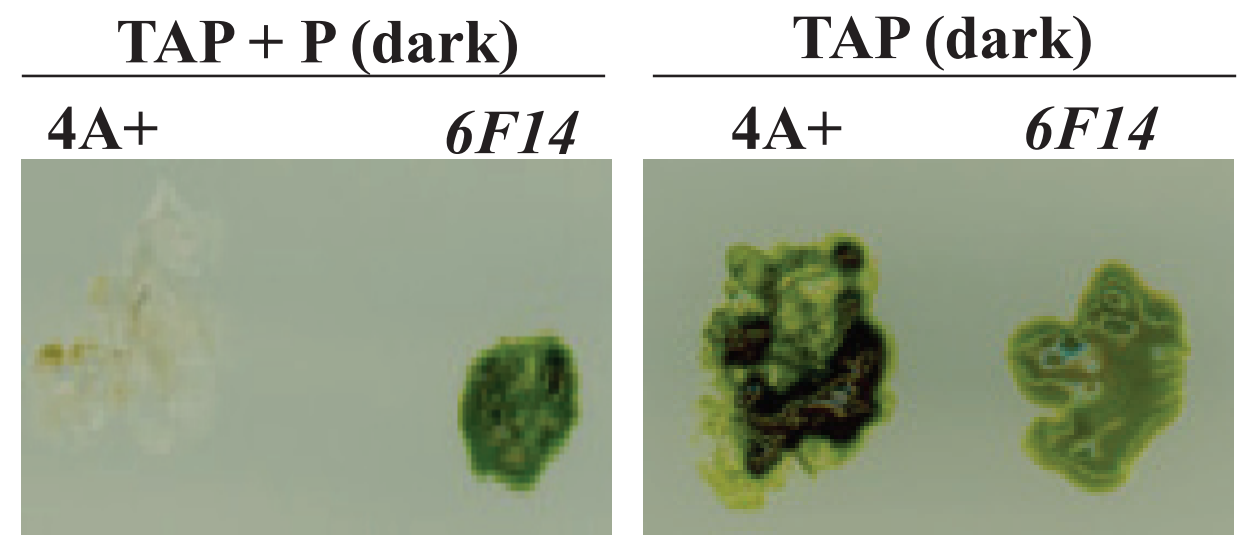

Figure 3. Identification of 6 F14. This figure shows the phenotypic difference of $6 F 14$ compared to the parental strain, $4 A+$ on heterotrophic agar media (TAP) plates under two different growth conditions: dark + paromomycin (P) and dark. 


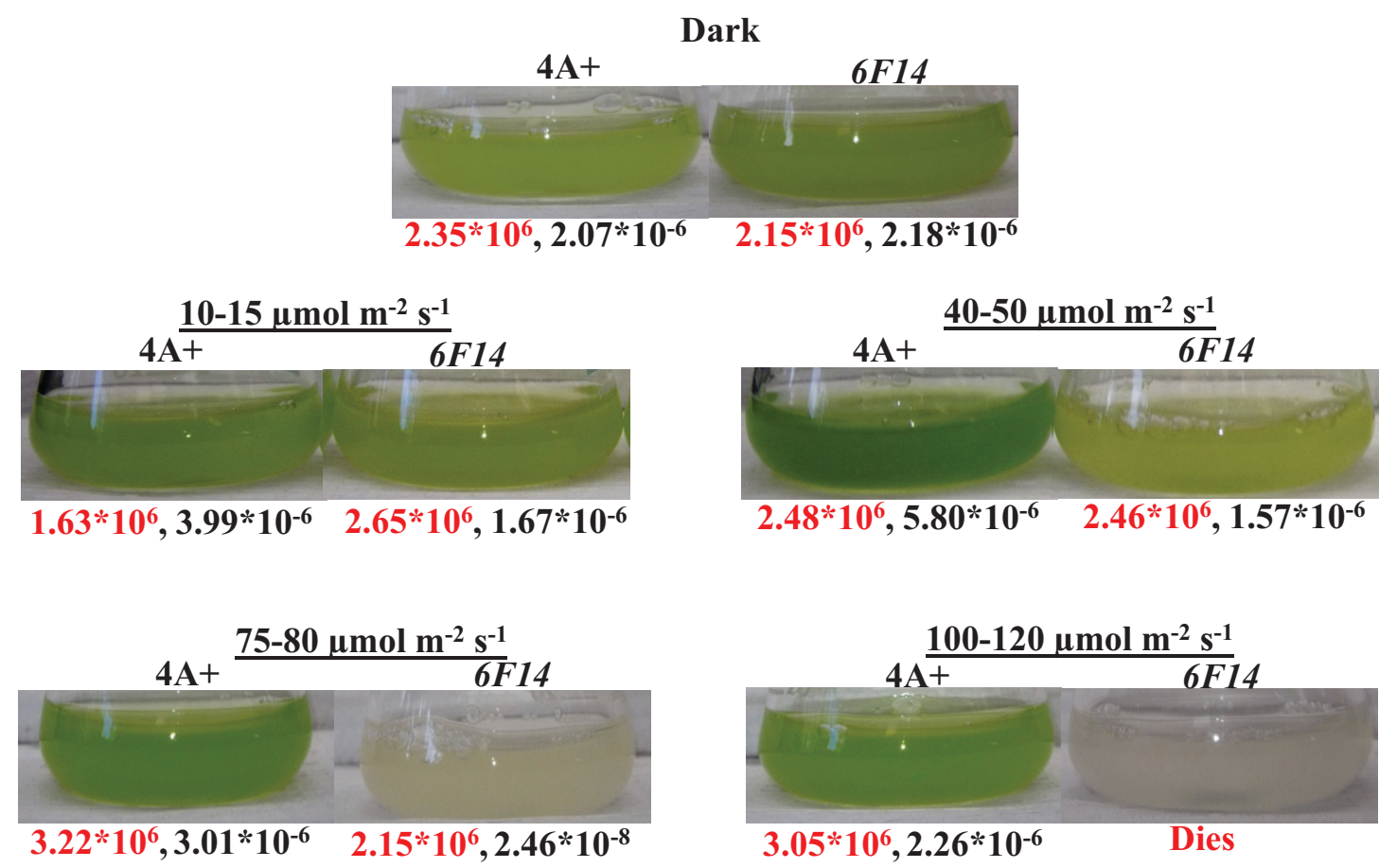

Figure 4. Heterotrophic and mixotrophic growth of 6 F14 and the wild-type in TAP media. Dark adapted cells of $6 F 14$ and $4 A+$ were shifted to different light intensities in this experiment. Light conditions and strains are labeled above the culture flasks. The cell density (cells/ml) and $\mathrm{nmol}$ chlorophyll (Chl) per cell are shown below the culture flasks in red and black numbers, respectively. For each light condition, experiments were performed on three biological replicates of each strain. Statistical error $( \pm S D)$ was $\leq 10 \%$.
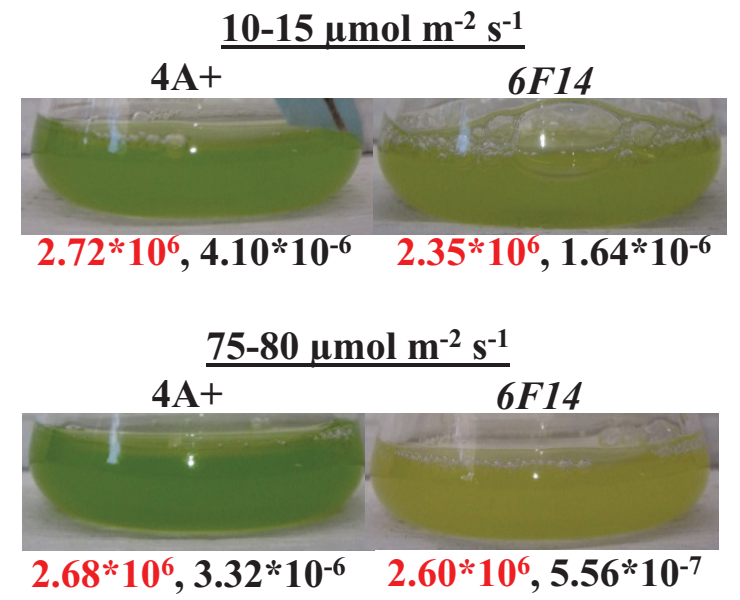

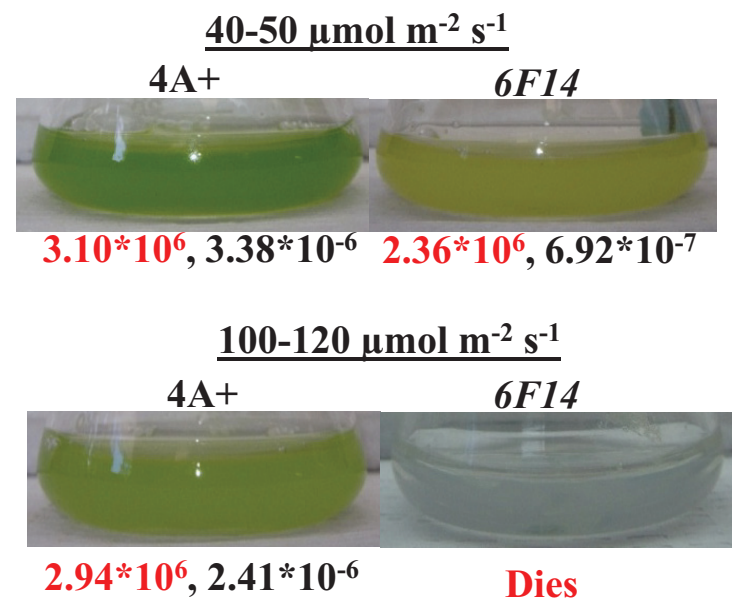

Figure 5. Photo-autotrophic growth of 6F14 and wild-type in HS media. Dark adapted cells of 6 F14 and 4A+ were shifted to different light intensities in this experiment. The mean cell density (cells/ml) and the Chlorophyll (Chl) content (nmol Chl per cell) are shown below the culture flasks in red and black numbers, respectively. For each light condition, experiments were performed on three biological replicates of each strain. Statistical error $( \pm S D)$ was $\leq 10 \%$.

reduction in $\mathrm{Chl} / \mathrm{cell}$ when moved to $40-50 \mu \mathrm{mol}$ photons $\mathrm{m}^{-2} \mathrm{~s}^{-1}$. When dim light adapted $6 F 14$ was shifted to $75-80 \mu \mathrm{mol}$ photons $\mathrm{m}^{-2} \mathrm{~s}^{-1}$, it showed a $98 \%$ reduction in Chl/cell while the dark adapted $6 F 14$ failed to survive under $75-80 \mu \mathrm{mol}$ photons $\mathrm{m}^{-2} \mathrm{~s}^{-1}$. Taken together, the results shown in Figure 4 and Figure 6 show that dark adapted $6 F 14$ is more sensitive to the magnitude of light intensity changes in the environment than the dim light adapted 6F14 (Figure 6).
Molecular characterization of the mutation in $6 F 14$

The linearized $\mathrm{pBC} 1$ plasmid was used to generate $6 F 14$ (Figure 2). To find the insertion of the APHVIII end of the plasmid in $6 F 14$, TAIL PCR method was employed. Figure 7A shows the position of the vector specific TAIL PCR primers and also shows the arbitrary position of the random degenerate primer. A $2.9 \mathrm{~kb}$ DNA product from TAIL2 PCR was purified from the agarose gel (Figure 7B, 
Shift to 40-50 umol photons $\mathrm{m}^{-2} \mathrm{~s}^{-1}$

Dim light adapted cells

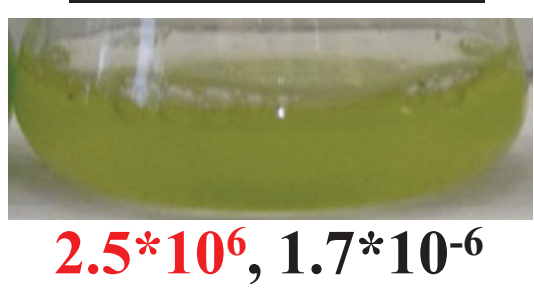

Dark adapted cells

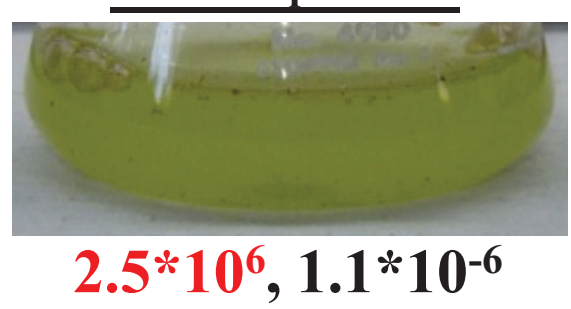

Shift to 75-80 $\mu$ mol photons $\mathrm{m}^{-2} \mathrm{~s}^{-1}$

Dim light adapted cells

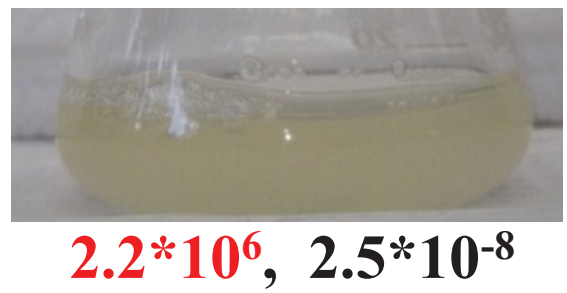

Dark adapted cells

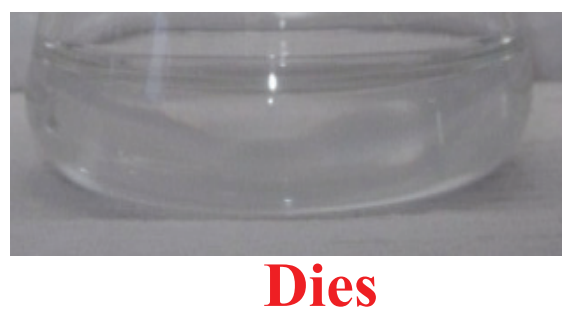

Figure 6. Effect of light shift on the growth of $\mathbf{6 F 1 4}$ and wild type. 6 F14 was adapted to dim light $\left(10-15 \mu \mathrm{mol}\right.$ photons $\left.\mathrm{m}^{-2} \mathrm{~s}^{-1}\right)$ or dark for one week in TAP media. Dark and dim light adapted cultures were then shifted to 40-50 or 75-80 $\mu$ mol photons $\mathrm{m}^{-2} \mathrm{~s}^{-1}$. The mean cell density (cells $/ \mathrm{ml}$ ) and the Chlorophyll (Chl) content (nmol Chl per cell) are shown below the culture flasks in red and black numbers, respectively. For each light condition, experiments were performed on three biological replicates of 6F14. Statistical error ( \pm SD) was $\leq 10 \%$. The average Chl content in the dim light and dark adapted 6F14 was $1.7 \times 10^{-6}$ and $2.18 \times 10^{-6} \mathrm{nmol} / \mathrm{cell}$.

Table 1). This purified DNA product was used for further PCR using internal primers specific to the $3^{\prime}$ UnTranslated Region (UTR) of the APHVIII gene. The PCR results confirmed that the $2.9 \mathrm{~kb}$ DNA product contains the $3^{\prime}$ UTR of the APHVIII gene (Figure 7 C). Sequencing of the $2.9 \mathrm{~kb}$ TAIL2 PCR product revealed that the APHVIII end of the plasmid has been inserted 344 bp away from the GUN4 gene (Cre05.g246800) on chromosome 5. The GUN4 locus was cleaved at least at two places (Figure 8). The first cleavage was about 781 bp away from the $5^{\prime}$ end of the GUN4 gene and the second cleavage was $1131 \mathrm{bp}$ away from the $3^{\prime}$ end of the GUN4 gene. These cleavages were followed by the inversion of the cleaved genomic DNA which then ligated to the 3' UTR of the GUN4 gene (Figure 8). Plasmid insertion also led to an addition of $29 \mathrm{bp}$ at the APHVIII end of the plasmid. An addition of $45 \mathrm{bp}$ was found at the breakage point in the $3^{\prime}$ UTR of the GUN4 gene (Figure 8).

Further genomic DNA PCR analyses with GUN4 specific primers confirmed that the $3^{\prime}$ part of the GUN4 first exon and the $5^{\prime}$ part of the GUN4 second exon were deleted or displaced (Figure 9). We also used primers specific to the genomic region upstream of the GUN4 gene and primers specific to the 3' UTR of a hypothetical gene, HYP2, (g5195) located downstream of GUN4 to see the extent of deletion on either side of the GUN4 gene. Our PCR analyses show that a $1.354 \mathrm{~kb}$ genomic DNA region, located upstream of
GUN4 was deleted/displaced. Additionally, there is a deletion of approximately $526 \mathrm{bp}$ in the $3^{\prime}$ UTR of the downstream HYP2 gene (Figure 10 and Figure 11). Taken together the data show that plasmid insertion in the $6 F 14$ genome has rearranged the GUN4 locus and has affected a part of the $3^{\prime}$ UTR of the HYP 2 gene. We do not yet know the exact location of the pUC ori end of the plasmid in the 6F14 genome (Figure 11).

Checking for the absence/presence of the transcript of the GUN4 and three neighboring genes of GUN4

Transcript levels of GUN4 and the neighboring genes (HYP1 [Cre05.g246750]; HYP2 [g5195] and SOXE [Cre05.g246900]) were checked using semi-quantitative RT-PCR using GUN4, HYP 1, HYP 2 and SOXE specific primers, respectively (Figure 12). Reduced levels of $H Y P 1$ and $H Y P 2$ transcripts were observed in 6 F14 compared to that in the wild type (Figure 12). GUN4 transcript is missing in $6 F 14$ as expected (Figure 12). The transcript level of SOXE, the second gene downstream of GUN4, was not affected. Cre05.g246750 and g5195 are genes in the Chlamydomonas database coding for hypothetical proteins. We have named these genes as HYP1 and HYP2 arbitrarily for our study. The SOXE gene codes for sulfocyanin, a blue copper protein. Readers are requested to identify GUN4 and its neighboring genes by the gene locus number (Cre or the $\mathrm{g}$ number) in the Phytozome database. 

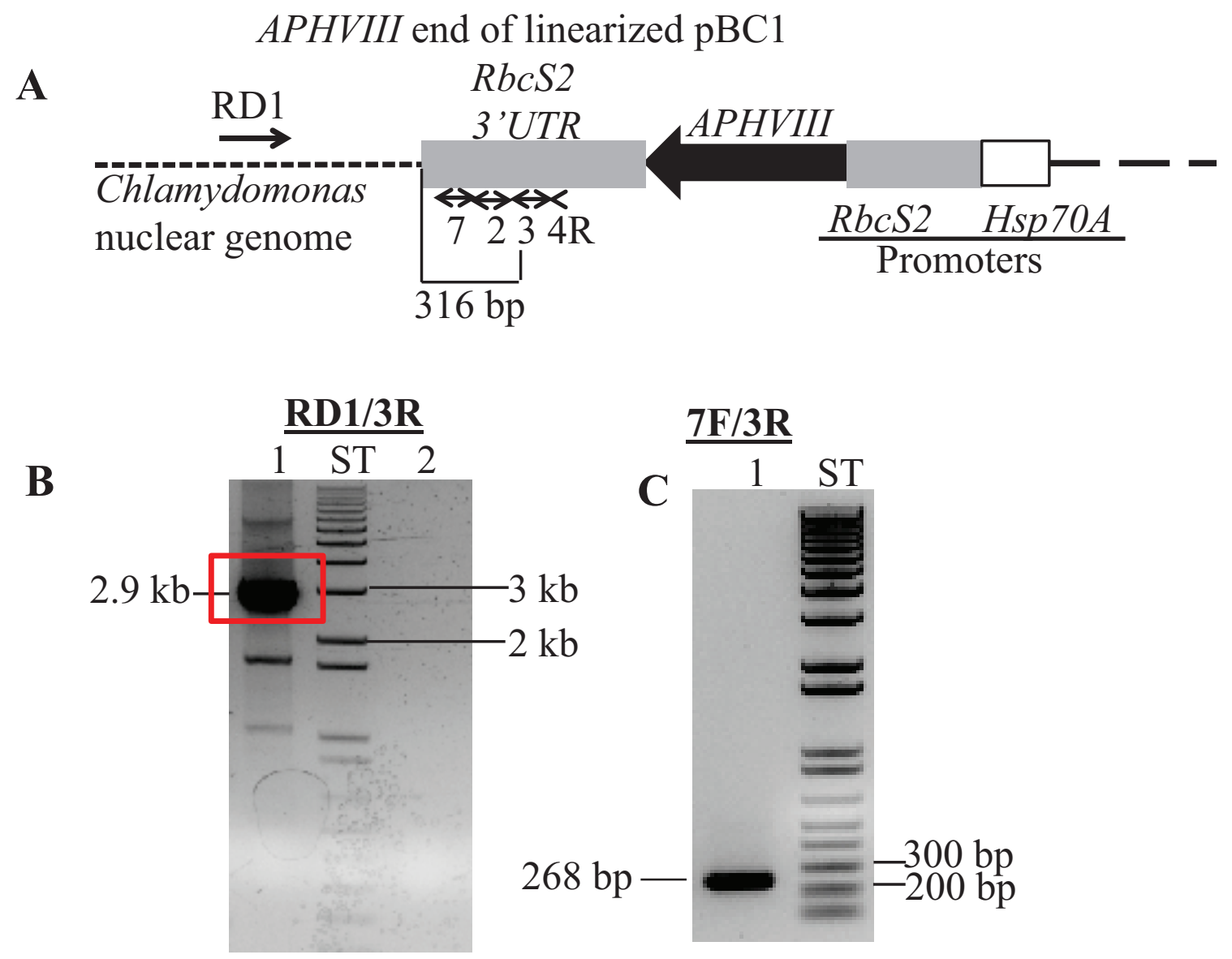

Figure 7. Locating the APHVIII flanking genomic sequence in 6F14. (A) A diagram showing a truncated pBC1 illustrating the APHVIII end of the linearized $\mathrm{pBC} 1$ vector. Primers used for PCR and DNA sequencing are shown by numbered black arrows. Thermal Asymmetric InterLaced1 (TAIL1) PCR was performed using primers 4R and RD1 (a random degenerate primer). (B) TAIL2 PCR was performed using primers 3R and RD1. In lane 1, 10-fold diluted TAIL1 PCR product was used for TAIL2 PCR; Lane 2 is a zero DNA control lane. The $2.9 \mathrm{~kb}$ TAIL2 PCR product used for DNA sequencing is highlighted in the red box. Initial DNA sequencing was performed using vector specific primers $2 R$ and 3R (Table 1). (C) Gel purified DNA product $(2.9 \mathrm{~kb})$ from TAIL2 PCR was used to verify if the product is specific to the APHVIII gene. PCR primer names are labeled on the top of the gel. PCR product size is labeled. F and R stand for forward and reverse primers, respectively. All primer sequences are shown in Table 1. ST stands for $1 \mathrm{~kb}$ plus ladder (Invitrogen, Carlsbad, CA). DNA samples were run on a $1 \%$ agarose gel.

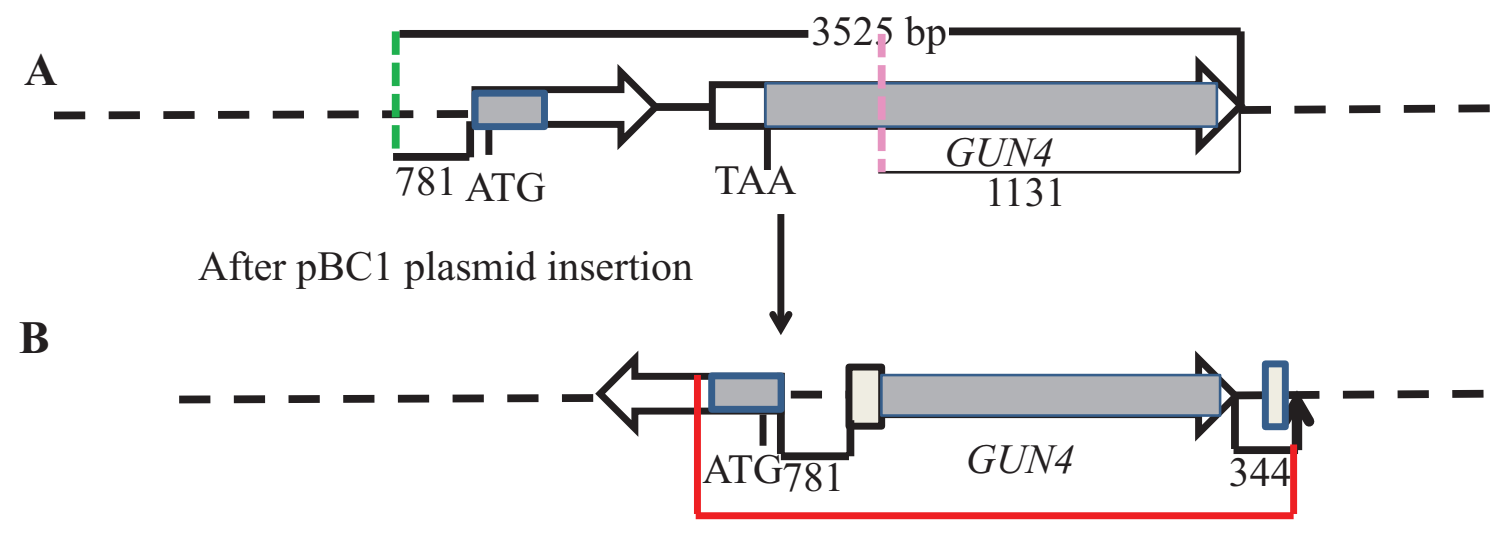

Figure 8. A schematic of the genetic rearrangement in 6F14. (A) A schematic genomic map showing a 3525 bp genomic DNA region spanning the GUN4 locus. The number at the bottom of the map denotes distance between respective points on the genomic DNA. The two GUN4 exons are represented by white block arrows. Grey boxes in GUN4 denote UnTranslated Regions (UTRs). The two break points are shown by the dashed pink and green lines. (B) A schematic diagram showing the rearrangement of the GUN4 locus after the insertion of the plasmid. The big and the small tan boxes, denote addition of 45 and $29 \mathrm{bp}$, respectively. The genomic DNA sequence obtained by sequencing the $2.9 \mathrm{~kb}$ Thermal Asymmetric InterLaced2 (TAIL2) PCR product is highlighted in red. The bold black small arrow indicates insertion point of the $\mathrm{pBC} 1$ plasmid. DNA sequencing was performed using GUN4 specific primers $2 \mathrm{R}, 7 \mathrm{~F}$ and $7 \mathrm{R}, 12 \mathrm{R}$ and $14 \mathrm{R}$. F and $\mathrm{R}$ stand for forward and reverse primers, respectively. Primer sequences are shown in Table 2. 

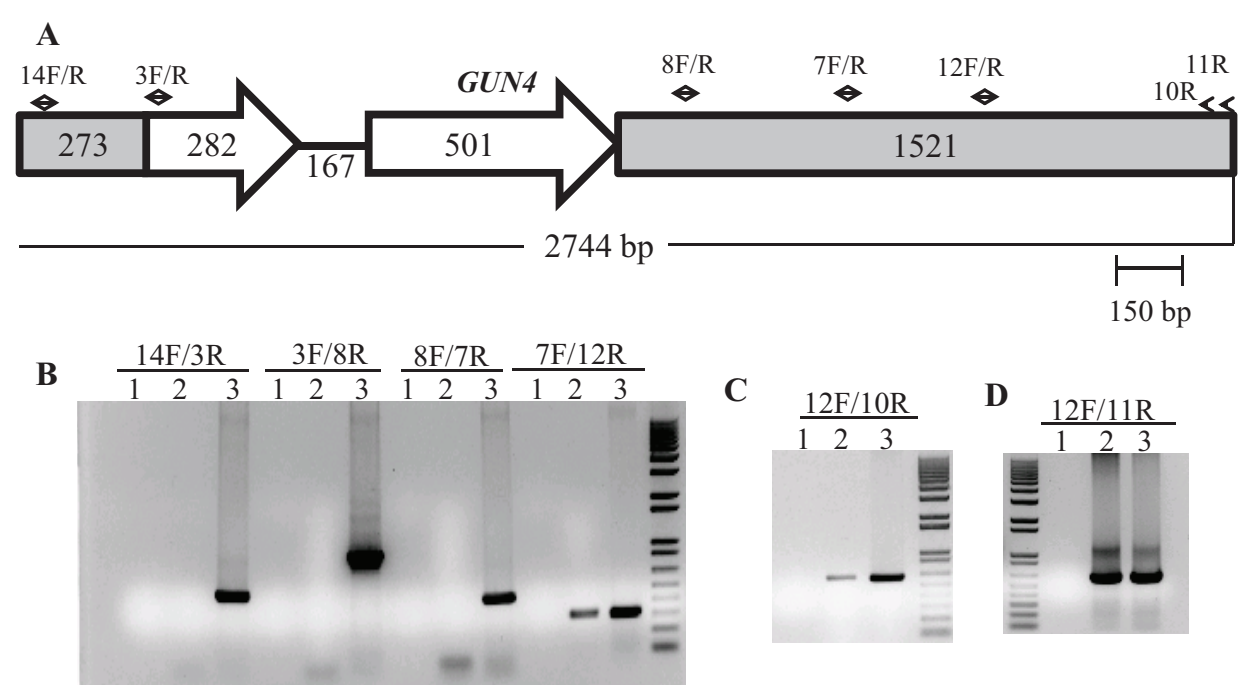

Figure 9. Genomic DNA analysis of 6 F14 and 4A+. (A) A schematic of the GUN4 gene. Small black arrows denote GUN4 specific primers. The two GUN4 exons are represented by white block arrows. Grey boxes in GUN4 denote UnTranslated Regions (UTRs). (B), (C) and (D) DNA gels showing DNA products obtained from genomic DNA PCR using GUN4 specific primers. Lanes 1, 2 and 3 are the zero DNA controls, 6F14 and 4A+, respectively. PCR primer names are labeled on the top of the gel. 14F/3R gives a 517 bp product while 3F/8R gives a 942 bp product. 8F/7R gives a 449 bp product. 7F/12R gives a 313 bp product. 12F/10R gives a 606 bp product and $12 F / 11 R$ gives a 623 bp product. F and R stand for forward and reverse primers, respectively. Primer sequences are shown in Table 2.
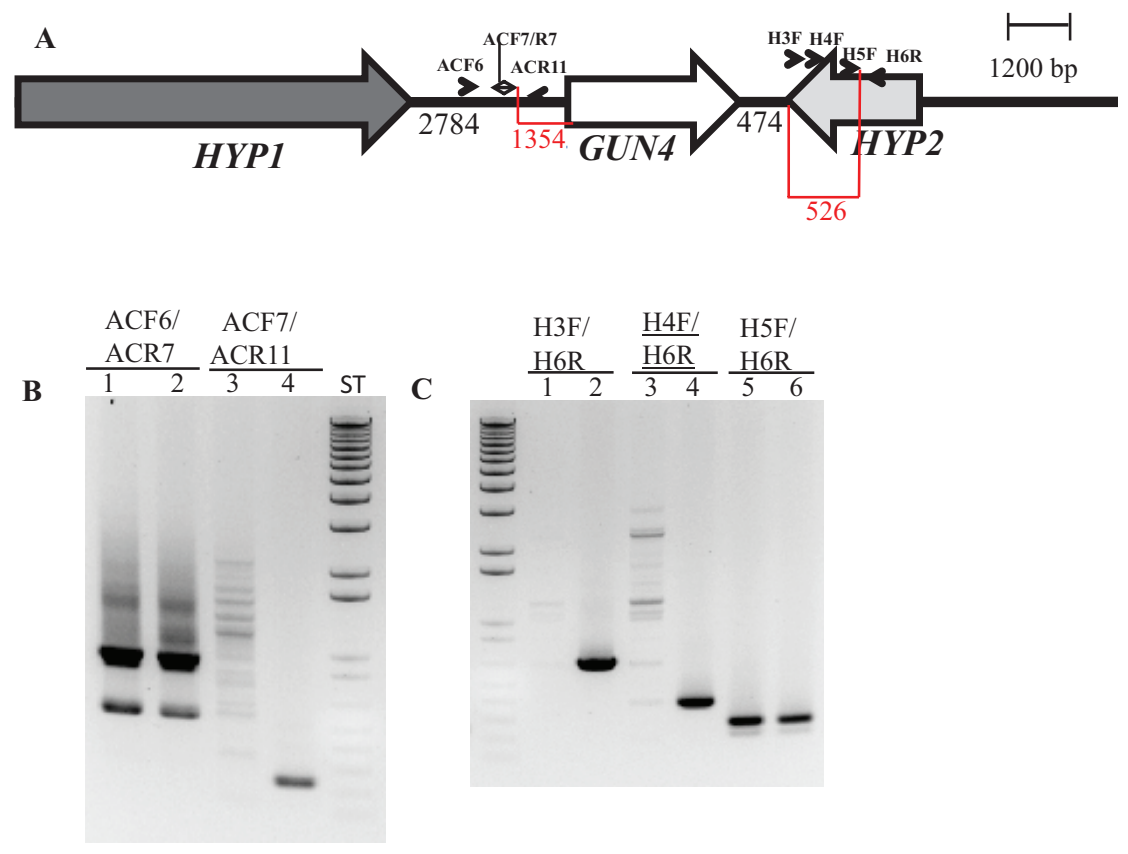

Figure 10. PCR using primers specific to the upstream region of GUN4 and the $\mathbf{3}^{\prime}$ UTR of the HYP2 gene. (A) A schematic diagram showing GUN4 (white arrow) and its two neighboring genes HYP1 (black arrow) and HYP2 (grey arrow). Black numbers at the bottom denote distances between respective genes. The two red highlighted regions and corresponding numbers show the distance between primer ACF7 and the start of the GUN4 gene and the distance between the primer H5F and the end of the HYP2 gene, respectively. Primers used for PCR are labeled. (B) A DNA gel showing the genomic DNA amplified using GUN4 upstream region specific primers. Lanes 1, 3 and 5: 6F14; Lanes 2, 4 and 6: 4A+. (C) A DNA gel showing the genomic DNA amplified using primers spanning the 3' UTR region of HYP2 gene. Lanes 1, 3 and 5: 6F14; Lanes 2, 4 and 6: 4A+. Product size of ACF6/ACR7: 937 bp (this primer set also produces a nonspecific 550 bp product); product size of ACF7/ACR11: 244 bp; product size of H3F/H6R: 667 bp; product size of H4F/H6R: 391 bp; product size of H5F/H6R: 278 bp. F and R stand for forward and reverse primers, respectively. Primer sequences are shown in Table 3. 

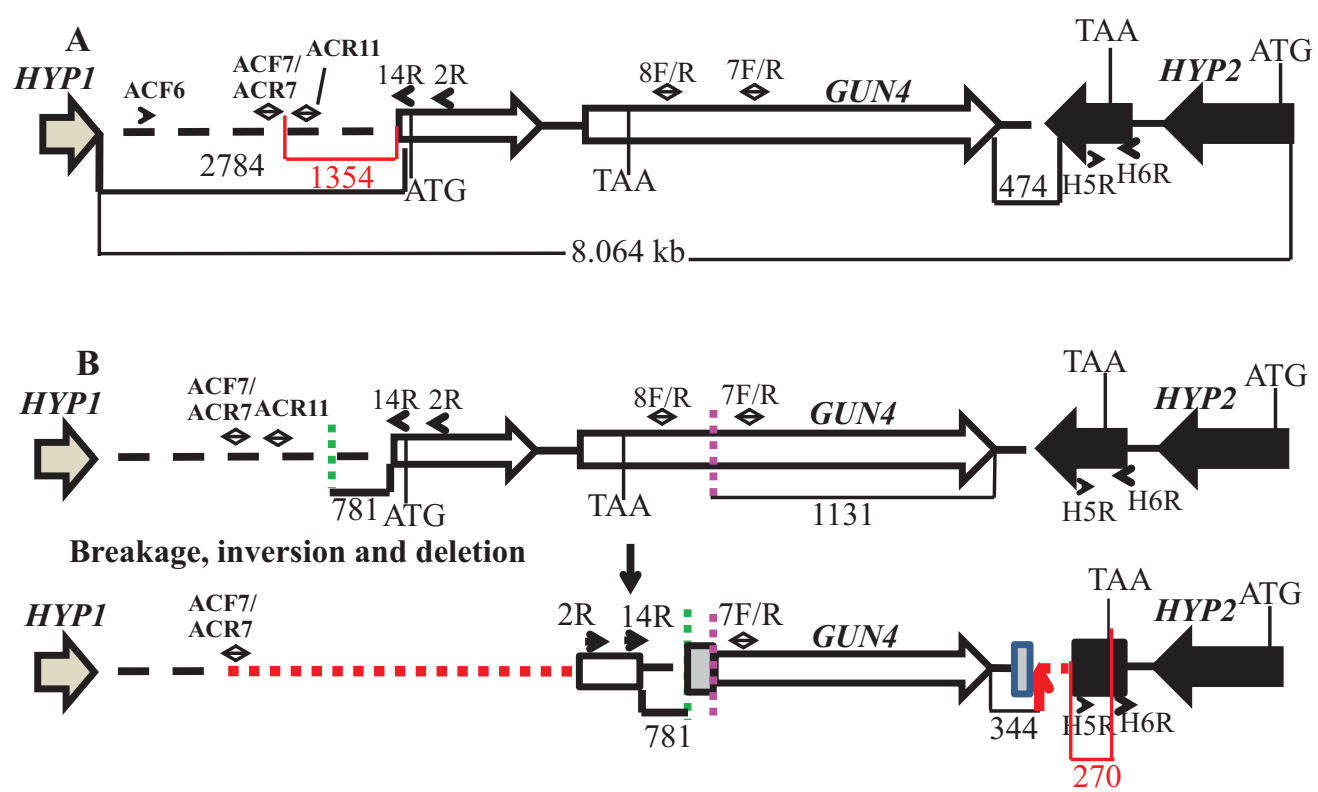

Figure 11. A schematic of the genetic rearrangement in 6F14. (A) A schematic genomic map showing an $8.064 \mathrm{~kb}$ genomic DNA region spanning the GUN4 locus on chromosome 5. The numbers at the bottom of the map denote distances between respective points on the genomic DNA. The red highlighted region and number show the distance between primer ACF7 and the start of the GUN4 gene and the distance between the primer H5F and the end of the HYP2 gene, respectively. The two GUN4 exons are represented by white block arrows. The tan arrow and the black block arrow, denotes a part of HYP1 3' UTR and HYP2 gene, respectively. (B) An updated schematic diagram showing the rearrangement of the GUN4 locus based on PCR analyses and DNA sequencing. Two break points in the genome are denoted by green and pink dashed lines. The big and the small grey boxes, denote addition of 45 and 29 bp, respectively. The small black arrows denote primers that were used for genomic PCRs in Figure 9 and Figure 10. Red dashed lines denote possible deletions. The small red arrow indicates the point of insertion of the pBC1 plasmid. The black numbers at the bottom of the map denote distances between respective points on the genomic DNA. The red highlighted region and the corresponding number show the distance between the end of the primer H5F and the stop codon of the HYP2 gene.

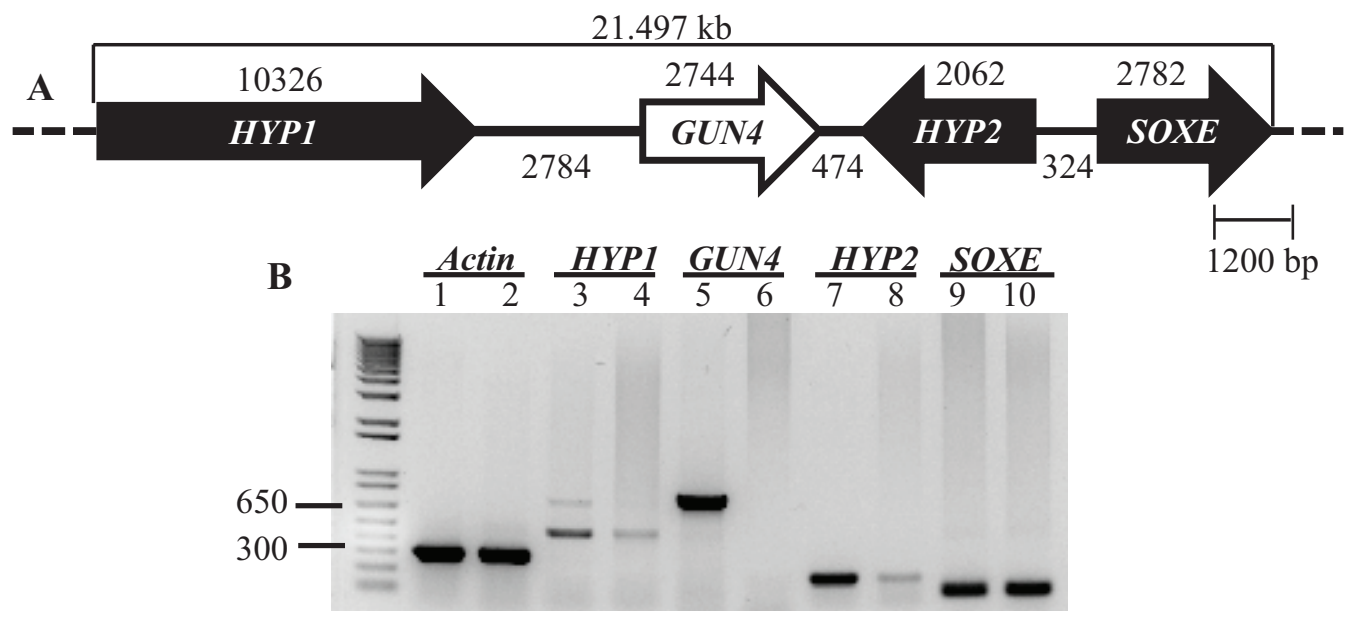

Figure 12. Transcript analyses of GUN4 and its neighboring genes. (A) A schematic map of a $21.497 \mathrm{~kb}$ genomic region spanning the GUN4 locus on chromosome 5. HYP1 and HYP2 are genes located upstream and downstream of the GUN4 gene, respectively coding for hypothetical proteins. Sulfocyanin (SOXE) codes for a blue copper protein. The top black number denotes size of a gene (bp) while the bottom black number denotes distance between genes (bp). (B) Semi-quantitative RT-PCR results. Lanes: 1, 3, 5, 7, 9 denote 4A+ cDNA products. Lanes 2, 4, 6, 8, 10 denote gun4 cDNA products. Primer sequences are shown in Table 4. All primers span an intron. Actin was used as a control. Actin genomic product size: 527 bp; Actin cDNA product size: 305 bp. HYP1 genomic product size 726 bp; HYP1 cDNA product size: 459 bp. GUN4 genomic product size: 942 bp; GUN4 cDNA product size 775 bp. HYP2 genomic product size: 797 bp; HYP2 cDNA product size: 184bp. SOXE genomic product size: $517 \mathrm{bp}$; SOXE cDNA product size: $119 \mathrm{bp}$ 
Complementation of $6 \mathrm{~F} 14$

We will be referring to $6 F 14$ as gun4 from here onward. As gun4 specifically lacks a functional GUN4 gene, we cloned the GUN4 gene in the pDBle vector to transform $6 F 14$ (Figure 13, Table 5). The trans GUN4 expression is driven by the constitutive $P s a D$ promoter in the GUN4-pDBle construct. pDBle has two Ble genes that confer resistance to the antibiotic zeocin. Figure 14 shows growth phenotypes of two gun4 complements (gun4-19 and gun4-27), $6 F 14$ and $4 \mathrm{~A}+$. gun4 complements are not light sensitive and are able to grow and photosynthesize under medium light intensities (300 $\mu \mathrm{mol}$ photons $\mathrm{m}^{-2} \mathrm{~s}^{-1}$ ) without photo-bleaching (Figure 14). As gun4 complements harbor the Ble gene (from the pDBle vector)

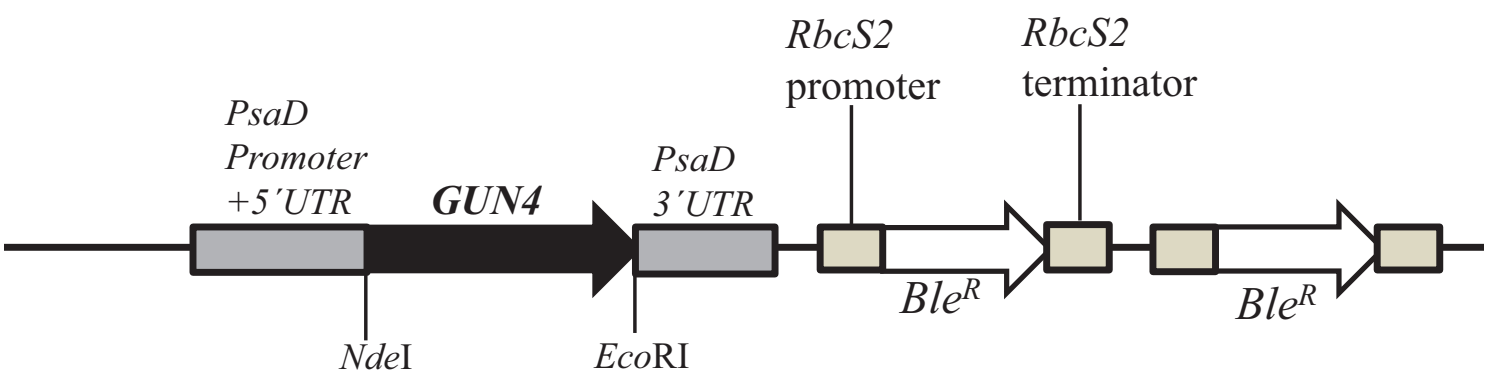

Figure 13. A schematic figure of the pDBle vector used for complementation of gun4. Ndel/EcoRI double digested GUN4 gene (956 bp) was cloned into the Ndel/EcoRI double digested pDBle plasmid. Primers used for amplification of the GUN4 gene are shown in Table 5. GUN4 expression is driven by the constitutive PsaD promoter. Ndel and EcoRI restriction sites are labeled. pDBle contains two copies of $B / e^{R}$ genes driven by the Rubisco (RbcS2) promoter. The size of the GUN4-pDBle construct is $7653 \mathrm{bp}$. The black arrow and the white arrow, denotes GUN4 and Ble $e^{R}$ genes, respectively. Grey and tan boxes denote UnTranslated Regions (UTRs).

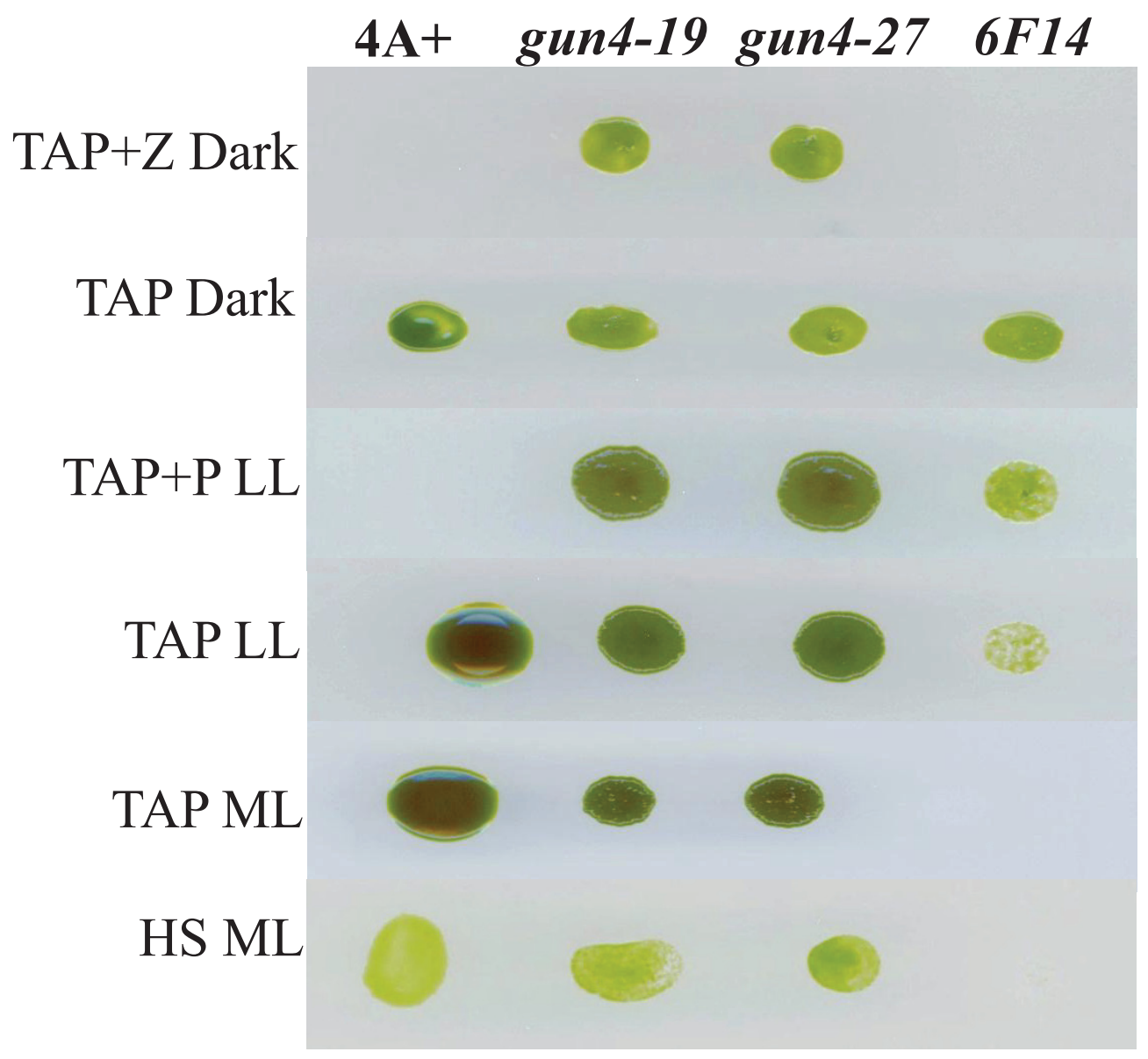

Figure 14. Growth phenotype analysis of gun4 complements. gun4-19 and gun4-27 complements, 6 F14 and $4 \mathrm{~A}+$ were grown for a week under six different growth conditions: TAP $+Z$ (zeocin) in the dark, TAP in the dark, TAP + P (paromomycin) low light (LL; $50 \mu m o l$ photons $\left.\mathrm{m}^{-2} \mathrm{~s}^{-1}\right)$, TAP LL, TAP medium light (ML; $300 \mu \mathrm{mol}$ photons $\mathrm{m}^{-2} \mathrm{~s}^{-1}$ ) and HS ML. 
and APHVIII gene (derived from the parental strain $6 F 14$ ), they can grow both on zeocin and paromomycin media plates unlike $6 F 14$ and 4A+ (Figure 14).

Chl analyses show that under heterotrophic conditions both gun 4 complements have $65-68 \%$ more $\mathrm{Chl}$ than that of the wild type cells (Figure 15). Under photo-autotrophic conditions gun4 complement cells possess 50-60\% more Chl than that of the wild type cells (Figure 15). Figure 16A shows a schematic figure of the trans GUN4 gene used for complementation. PCR analyses using the genomic DNA show that the gun 4 complements possess the functional trans GUN4 gene (Figure 16B, 16C and 16D). Figure 17A shows a stained protein gel that was loaded on equal Chl basis. Western analyses of the two gun 4 complements with a Chlamydomonas GUN4 specific antibody show that the GUN4 protein is absent in the gun4 mutant but present in the gun4 complements (Figure 17B). Western analyses also show that the two gun4 complements have higher levels of the GUN4 protein compared to that of the wild type (Figure 17B).

\section{Spectrophotometric chlorophyll analyses in $6 \mathrm{~F} 14,4 A+$ and gun4 complements}

3 Data Files

http://dx.doi.org/10.6084/m9.figshare.715886

\section{Discussion}

Plastid development and gene expressions are largely under nuclear "anterograde" control ${ }^{40}$. Additionally, chloroplast functional and developmental states can regulate expression of nuclear genes encoding chloroplast localized proteins via retrograde signaling ${ }^{40}$. The first evidence for the involvement of $\mathrm{Chl}$ biosynthetic precursors in retrograde signaling came from the work in Chlamydomonas ${ }^{41}$.
In Arabidopsis MgPPIX was hypothesized to be a retrograde signal from the chloroplast to the nucleus on the basis of data obtained with mutants that are defective in the norflurazon (NF) induced down-regulation of transcription of light harvesting complex protein B (LHCB)[gun (genomes uncoupled) phenotype] ${ }^{40,42}$. Six gun mutants are known; five of which directly influence tetrapyrrole biosynthesis (gun2-gun6) $)^{43,44}$. The gun4 mutation is localized to a porphyrin binding protein GUN4. GUN4 enhances the sensitivity of $\mathrm{MgChel}$ to $\mathrm{Mg}^{2+}$ at physiologically low $\mathrm{Mg}^{2+}$ concentration ${ }^{31,45}$. Cyanobacterial and higher plant GUN4 directly interacts with the CHLH subunit of MgChel and binds PPIX and MgPPIX, the substrate and the reaction product of the $\mathrm{MgChel}^{30,46-50}$. Although GUN4 is not an essential component of the MgChel complex, the presence of GUN4 markedly improves the enzyme activity in vitro by increasing the apparent substrate-binding capacity of CHLH for PPIX, particularly under low $\mathrm{Mg}^{2+}$ concentrations ${ }^{45,51,52}$. It is proposed that GUN4 upon porphyrin binding, stabilizes interactions between the catalytic subunit of $\mathrm{MgChel}$ and the chloroplast membranes, the site of Chl biosynthesis ${ }^{46,47}$. This enables $\mathrm{MgChel}$ to interact with enzyme complexes involved in the further downstream steps in the pathway ${ }^{46,47}$. Apart from its role in substrate channeling into the Chl synthesizing branch of tetrapyrrole biosynthesis, GUN4 has also been implicated in providing photo-protection under increasing light intensities $\mathrm{s}^{30,46,47}$. The porphyrin binding property of GUN4 has been implicated in ROS attenuation but conclusive experimental support is lacking ${ }^{47}$. In higher plants, GUN4 has been implicated as an essential component in a post-translational feedback regulation mechanism that modulates ALA biosynthesis in response to enzymatic activities of the $\mathrm{Mg}$ branch of tetrapyrrole biosynthesis as well as to the accumulating $\mathrm{Mg}$ porphyrin levels ${ }^{30}$ (Figure 1).

$6 F 14$ is the second gun4 mutant to be identified in C. reinhardtii. The first $C$. reinhardtii gun4 mutant was identified and characterized in 2012 by Formighieri et al. ${ }^{31}$. In this gun 4 mutant, 184 bp of the second exon of the GUN4 gene was deleted. In $6 F 14$ the plasmid
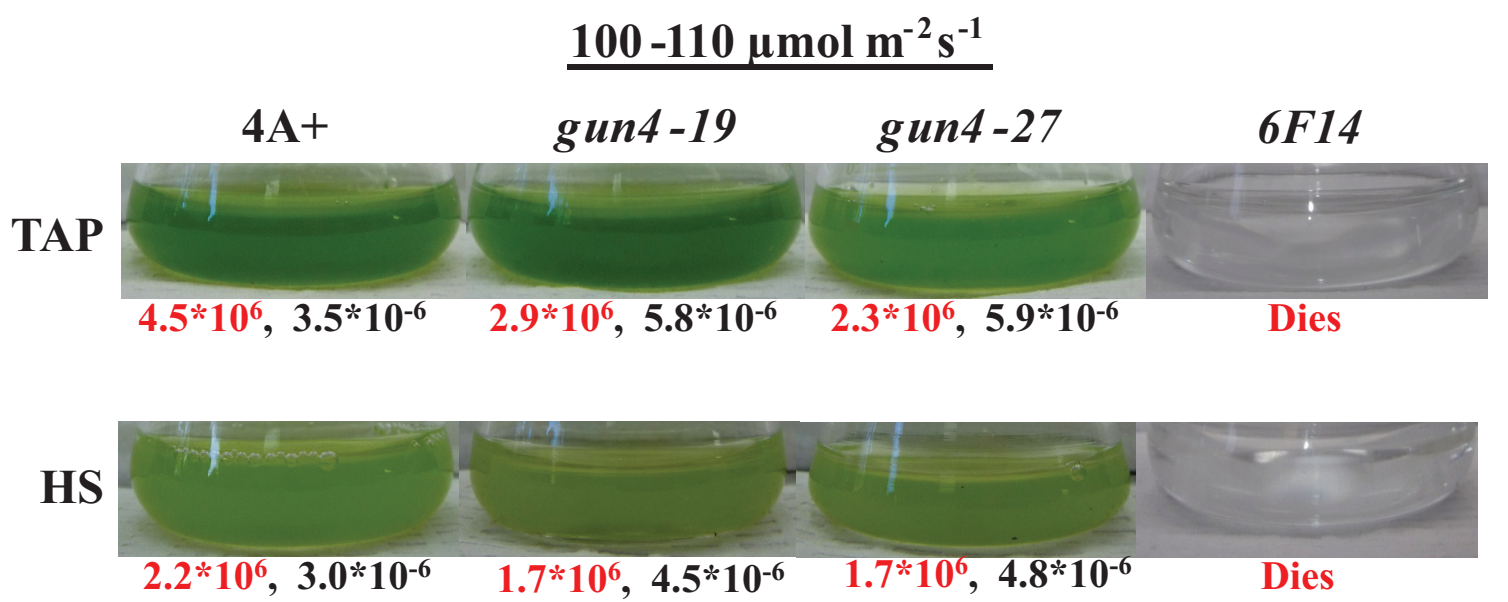

Figure 15. Mixotrophic and photo-autotrophic growth of gun4 complements. Light intensity is labeled above the culture flask. Growth media is labeled to the left of the culture flask. The mean cell density (cells/ml) and the Chlorophyll (Chl) content (nmol Chl per cell) are shown below the culture flasks in red and black numbers, respectively. For each light condition and growth condition, experiments were performed on three biological replicates of each strain. Statistical error $( \pm \mathrm{SD})$ was $\leq 10 \%$. 
A

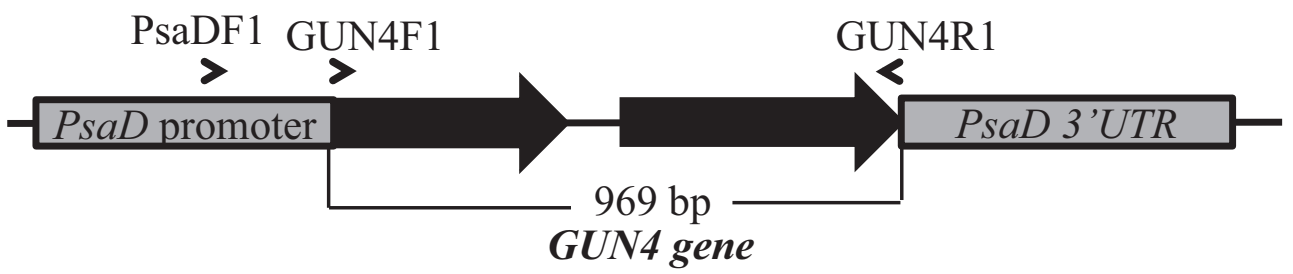

B

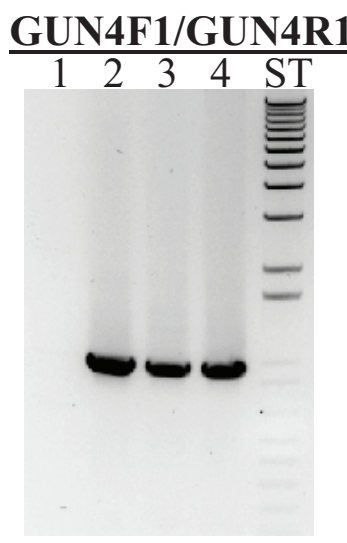

C GUN4F1/GUN4R1

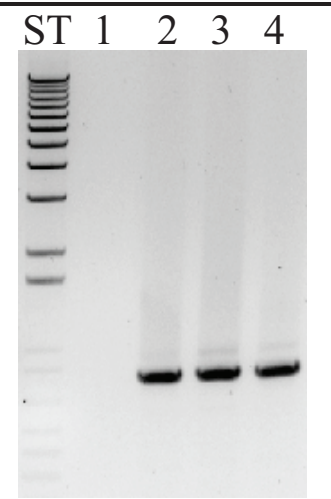

D PsaDF1/GUN4R1

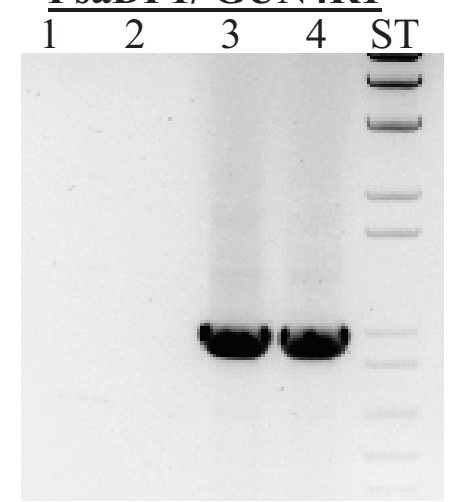

Figure 16. Molecular analyses of gun4 complements. (A) A schematic diagram of the GUN4-pDBle construct. Primers used for PCR are shown on the map. (B) Genomic DNA PCR analyses with GUN4 cloning primers (product size: 969 bp). Lane 1: gun4; Lane 2: 4A+; Lane 3: gun4-19; Lane 4: gun4-27. (C) RT-PCR analyses with GUN4 cloning primers (product size: 802 bp). Lane 1: gun4; Lane 2: 4A+; Lane 3: gun4-19; Lane 4: gun4-27. (D) Genomic PCR analyses using a PsaD 5' UTR specific forward primer with a GUN4 cloning reverse primer (product size: 976 bp). Lane 1: gun4; Lane 2: 4A+; Lane 3: gun4-19; Lane 4: gun4-27. Primer sequences are shown in Table 5.
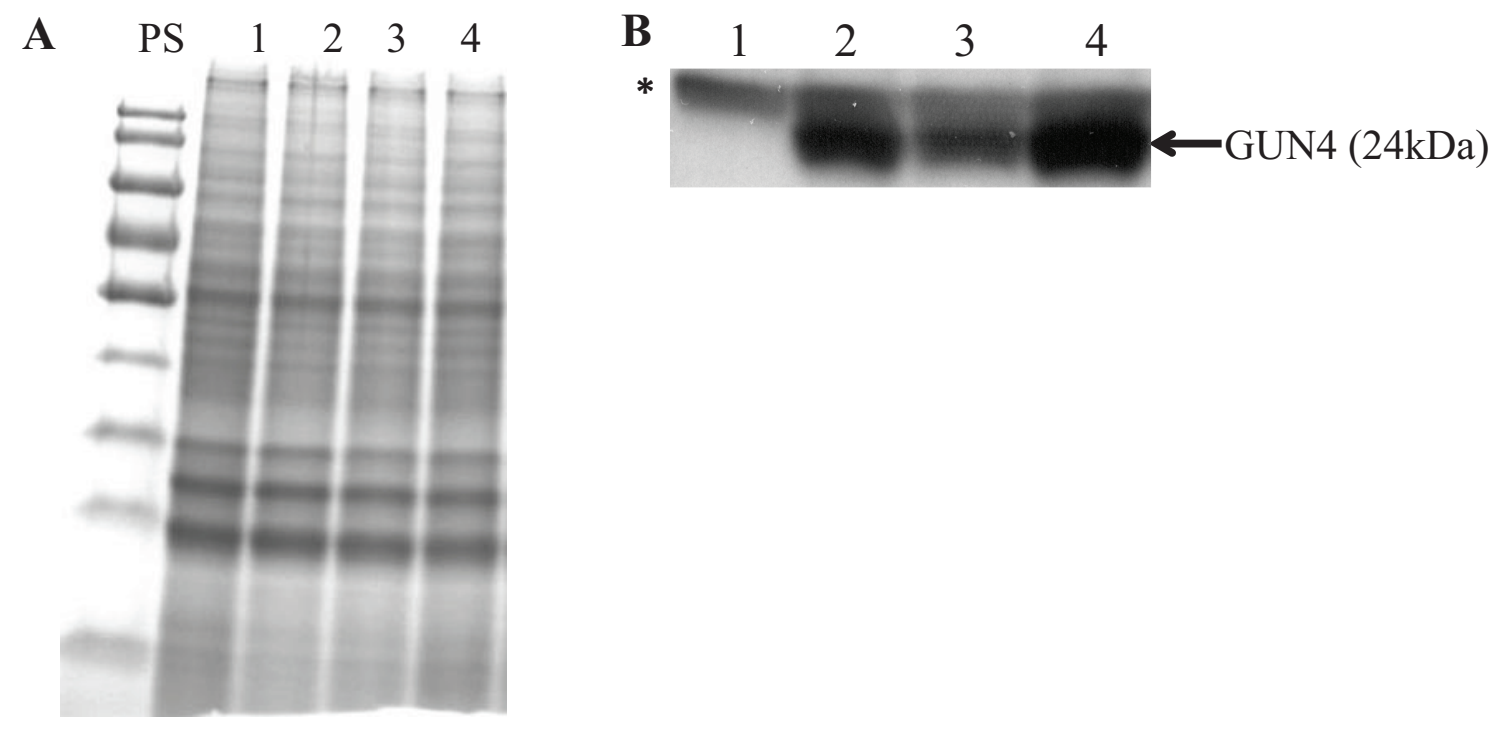

Figure 17. SDS-PAGE and Western analyses. (A) A stained protein gel. Lanes 1, 2, 3 and 4 represent gun4, gun4-19, 4A+ and gun4-27, respectively. PS denotes prestained molecular weight protein ladder. Total cell extract of different strains were loaded on equal Chlorophyll (Chl) basis (4 $\mathrm{gg}$ of Chl). (B) Western analyses using a GUN4 antibody generated against the Chlamydomonas mature full length GUN4 protein. Lanes 1, 2, 3 and 4 represent gun4, gun4-19, 4A+ and gun4-27, respectively. GUN4 (24kDa) protein detected by the antibody is labeled. * denotes a $25 \mathrm{kDa}$ protein detected non-specifically by the GUN4 antibody.

insertion outside the GUN4 gene has caused a genetic rearrangement of the GUN4 gene that prevented gene expression (Figure 11). Transcripts of GUN4 and the neighboring genes of GUN4 in $6 F 14$ were checked by performing semi-quantitative reverse transcription
PCR. In $6 F 14$, the transcript level of the first downstream hypothetical (HYP2) gene was lower than that in the wild type (Figure 12). The plasmid insertion in $6 F 14$ has led to a deletion of part of the 3' UTR region of the HYP2 gene (270 bp away from the stop codon 
of the coding region of $H Y P 2$; Figure 11). The $3^{\prime}$ UTR is usually responsible for the stability of the transcript. Hence the nature of the deletion in $H Y P 2$ explains the decrease in transcript levels of $H Y P 2$. GUN4 and the upstream gene, HYP1, are separated from each other by $2.784 \mathrm{~kb}$ (Figure 10). There is a possible deletion/ genetic rearrangement in the $5^{\prime}$ genomic region upstream of the GUN4 which does not extend into the HYP1 gene (Figure 10 and Figure 11). Although the transcription of $H Y P 1$ was not hampered, the HYPl transcript level is lower in our gun4 compared to that in the wild type (Figure 12). Based on the RT-PCR analyses, it is speculated there might be some uncharacterized downstream regulatory sequences present in the $2.784 \mathrm{~kb}$ region that might regulate HYP1 transcription. In future, quantitative real time-PCR experiments can be used to accurately quantify transcript levels of HYP1 and $H Y P 2$ in $6 F 14$.

The photosensitive phenotype of our gun 4 mutant resembles that of the earlier identified Chlamydomonas gun4 mutant. Overaccumulation of photo-excitable PPIX leads to photo-oxidative damage to the cells in presence of light and oxygen ${ }^{4,26,53}$. The light sensitivity of $6 F 14$ is most probably due to an over-accumulation of the PPIX which occurs due to the inactivity of MgChel enzyme as has been shown by Formighieri et al. $(2012)^{31}$ in their gun4 mutant. Future HPLC (High Performance Liquid Chromatography) analyses of steady state tetrapyrrole intermediates in $6 F 14$ will confirm this hypothesis. Formighieri et al. (2012) $)^{31}$ explored four light conditions (dark, 6-, 50-, and $500 \mu \mathrm{mol}$ photons $\mathrm{m}^{-2} \mathrm{~s}^{-1}$ ) and showed that the gun4 Chlamydomonas mutant dies under high light $\left(500 \mu \mathrm{mol}\right.$ photons $\left.\mathrm{m}^{-2} \mathrm{~s}^{-1}\right)$. These researchers did not explore or clarify the maximum light irradiance condition that can be tolerated by the Chlamydomonas gun4 mutant in heterotrophic and photosynthetic growth conditions. In this study, we found that $6 F 14$ photo-bleached at 75-80 $\mu \mathrm{mol}$ photons $\mathrm{m}^{-2} \mathrm{~s}^{-1}$ and could not tolerate light intensity above $100 \mu \mathrm{mol}$ photons $\mathrm{m}^{-2} \mathrm{~s}^{-1}$ (Figure 4 and Figure 5). The earlier identified C. reinhardtii gun 4 was able to grow in continuous light slightly better than in photoperiodic shifts ${ }^{31}$. In Arabidopsis, the gun4 mutant was seen to exhibit significant improved growth in continuous light compared to periodic shifts in light $^{30}$. In this study, $6 F 14$ and the wild type were adapted to dark or dim light and then shifted to two different light irradiances (40-50 $\mu \mathrm{mol}$ photons $\mathrm{m}^{-2} \mathrm{~s}^{-1}$ and 75-80 $\mu \mathrm{mol}$ photons $\mathrm{m}^{-2} \mathrm{~s}^{-1}$ ). Cultures exposed to light shifts showed a significant reduction in the $\mathrm{Chl}$ content than those grown under a constant light intensity (Figure 4 and Figure 6). Additionally, dark adapted 6 F14 showed a significant reduction in the $\mathrm{Chl}$ content compared to the dim light adapted $6 F 14$, when cells were shifted to similar light intensities (Figure 6). These results show that $6 F 14$ is very sensitive to the magnitude of light intensity fluctuations in the environment unlike the earlier reported Chlamydomonas gun 4 mutant ${ }^{31}$. Our light shift experimental results support the findings in cyanobacterial and Arabidopsis gun4 mutants ${ }^{30,48-50}$.

By spectrophotometric analysis we have shown that in the dark 6F14 possesses almost similar Chl content like that in the wild type (Figure 4). This phenotype is very different from that of the previously identified Chlamydomonas gun4 mutant which possesses $50 \%$ of the wild type level of $\mathrm{Chl} / \mathrm{cell}^{31}$ in the dark. Variation in $\mathrm{Chl} /$ cell in the dark between the two $C$. reinhardtii gun4 mutants could possibly be due to a variation of the parental strain's ability to synthesize $\mathrm{Chl}$ in the dark. The parental strain used by Formighieri et al. $(2012)^{31}$ was $\mathrm{cw} 15 \mathrm{mt}$ - . However, the $50 \%$ decrease in Chl seen in the previously described Chlamydomonas gun4 mutant was determined through HPLC analyses. Hence the discrepancy in Chl content in the two gun4 mutants could be due to the sensitivity of the HPLC method compared to that of the spectrophotometric method used for Chl assays.

Interestingly, it has been shown by Formighieri et al. (2012) $)^{31}$ that Chlamydomonas gun4 complements expressing more GUN4 protein grow better under high light and that there is no correlation between the accumulation of PPIX and the ability to grow better under high light ${ }^{31}$. However these gun 4 complements were not over-expressers of the GUN4 protein compared to the wild type strain $c w 15$, used in their experiments ${ }^{31}$. Our two gun 4 complements (gun4-19 and gun4-27) are over-expressing the GUN4 protein compared to the wild type strain $4 \mathrm{~A}+$ in the dim light (Figure 17B). These two gun4 complements open up new avenues to test if GUN4 has a distinct photo-protective role that is independent from the PPIX-induced GUN4 photo-protective role proposed by several researchers ${ }^{46,47}$. Comparative growth studies, quantitative measurements of GUN4 transcripts by Real Time PCR, GUN4 protein levels by Western analyses and PPIX content by HPLC analyses of the high light- $\left(500 \mu \mathrm{mol}\right.$ photons $\left.\mathrm{m}^{-2} \mathrm{~s}^{-1}\right)$ and $\operatorname{dim}$ light- $\left(15-20 \mu \mathrm{mol}\right.$ photons $\left.\mathrm{m}^{-2} \mathrm{~s}^{-1}\right)$ adapted gun 4 complements and the wild type strain will help to confirm if GUN4 has a distinct photoprotective role that is independent of tetrapyrrole metabolism.

Taken together our work reconfirms the results of other researchers who have studied GUN4 in other photosynthetic organisms $^{30,31,46,47,49,50}$. Although loss of GUN4 caused a perturbation in Chl biosynthesis in our gun4 mutant, the effect is not as dramatic as it is in Arabidopsis, where the loss of GUN4 results in a nearly albino mutant ${ }^{51}$. The earlier identified Chlamydomonas gun 4 mutant phenotypically resembles our gun4 mutant ${ }^{31}$. Therefore it seems that in $C$. reinhardtii $\mathrm{Chl}$ biosynthesis is less dependent on the GUN4 function. One explanation for this difference in the mutant phenotype could be that Chlamydomonas is capable of synthesizing $\mathrm{Chl}$ in the dark unlike the angiosperms. GUN4 binds PPIX and acts at the branch point in the tetrapyrrole biosynthetic pathway where PPIX is diverted to heme and Chl biosynthesis. Hence, although GUN4 has a conserved physiological role in all oxygenic photosynthetic organisms, it might have a somewhat different role in different evolutionary groups depending on the channelization of PPIX into the heme and Chl branch in the pathway.

\section{Author contributions}

MM and PG conceived the study, designed the experiments and took the lead role in preparing the manuscript. KG generated the mutant $6 F 14$. PG did the PCR analyses, isolated genomic DNA, performed growth and $\mathrm{Chl}$ analyses of different strains, prepared cDNA, cloned the GUN4 gene and complemented the mutant 6F14. $\mathrm{KG}$ and SP maintained all the strains and were involved in the mutagenesis experiment. KL and DW isolated genomic DNA and performed PCRs. MM performed the TAIL-PCR analyses, extracted TAIL-PCR product from agarose gels, prepared DNA 
samples for sequencing and analyzed the DNA sequencing data and also performed the protein and Western analyses. All authors were involved in the revision of the manuscript draft and have agreed to the final content.

\section{Competing interests}

No competing interests were disclosed.

\section{Grant information}

This project was supported by several grants awarded to Dr. Mautusi Mitra. These are: the start-up grant of the University of West Georgia (UWG), the Faculty Research Grant by the UWG College of Science and Mathematics, the Internal Development Grant by the UWG office of Research and Sponsored Project, the Research Incentive grant by the UWG College of Science and Mathematics, the UWG Student Research Assistance Program (SRAP) grant and the UWise-BOR-STEM II grant from UWG.
The funders had no role in study design, data collection and analysis, decision to publish, or preparation of the manuscript.

\section{Acknowledgements}

We would like to thank Dr. Krishna K. Niyogi (UC, Berkeley) for providing the $4 \mathrm{~A}+$ strain and the $\mathrm{pBC} 1$ plasmid that were used for mutagenesis and the GUN4 antibody for Western analyses. We are grateful to Dr. Saul Purton (University College London, UK) for providing the complementation vector pDBle. We are grateful to Dr. Bernhard Grimm and Dr. Pawel Brzezowski (Humboldt University, Berlin, Germany) for providing us the SOXE gene specific primers for RT-PCR analyses. We would also like to thank Dr. Leos Kral (University of West Georgia) for allowing us to use his nano spectrophotometer and Dr. Anastasios Melis (UC, Berkeley) for allowing us to perform the protein and Western analyses at his laboratory.
1. Merchant SS, Prochnik SE, Vallon O, et al:: The Chlamydomonas genome reveals the evolution of key animal and plant functions. Science. 2007; 318(5848): 245-250.

PubMed Abstract | Publisher Full Text | Free Full Text

2. Dent RM, Haglund $\mathrm{CM}$, Chin BL, et al.: Functional genomics of eukaryotic photosynthesis using insertional mutagenesis of Chlamydomonas reinhardtii. Plant Physiol. 2005; 137(2): 545-556.

PubMed Abstract | Publisher Full Text | Free Full Text

3. Gutman BL, Niyogi KK: Chlamydomonas and Arabidopsis A dynamic duo. Plant Physiol. 2004; 135(2): 607-610.

PubMed Abstract | Publisher Full Text | Free Full Text

4. Beale SI: Green genes gleaned. Trends Plant Sci. 2005; 10(7): 309-312. PubMed Abstract | Publisher Full Text

5. Grossman AR, Lohr M, Im CS: Chlamydomonas reinhardtii in the landscape of pigments. Annu Rev Genet. 2004; 38: 119-173. PubMed Abstract | Publisher Full Text

6. Walker CJ, Willows RD: Mechanism and regulation of Mg-chelatase. Biochem J. 1997; 327(Pt 2): 321-333. PubMed Abstract | Free Full Text

7. Armstrong GA, Runge S, Frick G, et al:: Identification of NADPH:protochlorophyllide oxidoreductases $A$ and $B$ : a branched pathway for light-dependent chlorophyll biosynthesis in Arabidopsis thaliana. Plant Physiol. 1995; 108(4): 1505-1517. PubMed Abstract | Publisher Full Text | Free Full Text

8. Oosawa N, Masuda T, Awai $\mathrm{K}$, et al.: Identification and light-induced expression of a novel gene of NADPH-protochlorophyllide oxidoreductase isoform in Arabidopsis thaliana. FEBS Lett. 2000; 474(2-3): 133-136. PubMed Abstract | Publisher Full Text

9. Reinbothe $\mathrm{S}$, Reinbothe $\mathrm{C}$ : Regulation of chlorophyll biosynthesis in angiosperms. Plant Physiol. 1996; 111(1): 1-7.

PubMed Abstract | Publisher Full Text | Free Full Text

10. Su Q, Frick G, Armstrong G, et al:: POR C of Arabidopsis thaliana: a third light- and NADPH-dependent protochlorophyllide oxidoreductase that is differentially regulated by light. Plant Mol Biol. 2001; 47(6): 805-813. PubMed Abstract | Publisher Full Text

11. Fujita $\mathrm{Y}$, Takahashi $\mathrm{Y}$, Chuganji $\mathrm{M}$, et al:: The nifH-like (frx $C)$ gene is involved in the biosynthesis of chlorophyll in the filamentous cyanobacterium Plectonema boryanum. Plant Cell Physiol. 1992; 33(1): 81-92. Reference Source

12. Fujita $\mathrm{Y}$, Matsumoto $\mathrm{H}$, Takahashi $\mathrm{Y}$, et al:: Identification of a nifDK-like gene (ORF467) involved in the biosynthesis of chlorophyll in the cyanobacterium Plectonema boryanum. Plant Cell Physiol. 1993; 34(2): 305-314. PubMed Abstract

13. Fujita $\mathrm{Y}$, Takagi $\mathrm{H}$, Hase $\mathrm{T}$ : Identification of the chIB gene and the gene product essential for the light-independent chlorophyll biosynthesis in the cyanobacterium Plectonema boryanum. Plant Cell Physiol. 1996; 37(3): 313-323. PubMed Abstract

14. Fujita $\mathrm{Y}$, Takagi $\mathrm{H}$, Hase $\mathrm{T}$ : Cloning of the gene encoding a protochlorophyllide reductase: the physiological significance of the co-existence of lightdependent and -independent protochlorophyllide reduction systems in the cyanobacterium Plectonema boryanum. Plant Cell Physiol. 1998; 39(2): 177-185. PubMed Abstract

15. Fujita Y, Bauer CE: Reconstitution of light-independent protochlorophyllide reductase from purified bchL and $\mathrm{BchN}-\mathrm{BchB}$ subunits. In vitro confirmation of nitrogenase-like features of a bacteriochlorophyll biosynthesis enzyme. J Biol Chem. 2000; 275(31): 23583-23588.

PubMed Abstract | Publisher Full Text

16. Fujita $Y$, Bauer C: The light-independent protochlorophyllide reductase: a nitrogen-like enzyme catalyzing a key reaction for greening in dark. In: Kadish KM, Smith KM, Guilard R, eds, The Porphyrin Handbook, Amsterdam: Academic Press. 2003; 13: 109-156.

17. Nomata J, Swem LR, Bauer CE, et al.: Overexpression and characterization of dark-operative protochlorophyllide reductase from Rhodobacter capsulatus. Biochim Biophys Acta. 2005; 1708(2): 229-237.

PubMed Abstract | Publisher Full Text

18. Nomata J, Ogawa T, Kitashima M, et al:: NB-protein (BchN-BchB) of dark-operative protochlorophyllide reductase is the catalytic component containing oxygen-tolerant Fe-S clusters. FEBS Lett. 2008; 582(9): 1346-1350. PubMed Abstract | Publisher Full Text

19. Shui J, Saunders E, Needleman R, et al:: Light-dependent and light-independent protochlorophyllide oxidoreductases in the chromatically adapting cyanobacterium Fremyella diplosiphon UTEX 481. Plant Cell Physiol. 2009; 50(8): 1507-1521. PubMed Abstract | Publisher Full Text

20. Yamamoto $\mathrm{H}$, Kurumiya $\mathrm{S}$, Ohashi R, et al:: Oxygen sensitivity of a nitrogenaselike protochlorophyllide reductase from the cyanobacterium Leptolyngbya boryana. Plant Cell Physiol. 2009; 50(9): 1663-1673. PubMed Abstract | Publisher Full Text

21. Sakuraba $\mathrm{Y}$, Yamasato $\mathrm{A}$, Tanaka R, et al.: Functional analysis of $\mathrm{N}$-terminal domains of Arabidopsis chlorophyllide a oxygenase. Plant Physiol Biochem. 2007; 45(10-11): 740-749. PubMed Abstract | Publisher Full Text

22. Tanaka A, Ito $\mathrm{H}$, Tanaka $\mathrm{R}$, et al.: Chlorophyll a oxygenase (CAO) is involved in chlorophyll $\boldsymbol{b}$ formation from chlorophyll a. Proc Natl Acad Sci U S A. 1998; 95(21): 12719-12723. PubMed Abstract | Publisher Full Text | Free Full Text

23. Tanaka R, Tanaka A: Effects of chlorophyllide a oxygenase overexpression on light acclimation in Arabidopsis thaliana. Photosynth Res. 2005; 85(3): 327-340. PubMed Abstract | Publisher Full Text

24. Yamasato A, Nagata N, Tanaka R, et al.: The N-terminal domain of chlorophyllide a oxygenase confers protein instability in response to chlorophyll $B$ accumulation in Arabidopsis. Plant Cell. 2005; 17(5): 1585-1597. PubMed Abstract | Publisher Full Text | Free Full Text

25. Meguro M, Ito H, Takabayashi A, et al:: Identification of the 7-hydroxymethyl chlorophyll a reductase of the chlorophyll cycle in Arabidopsis. Plant Cell. 2011; 23(9): 3442-3453.

PubMed Abstract | Publisher Full Text | Free Full Text

26. Moulin M, Smith AG: Regulation of tetrapyrrole biosynthesis in higher plants. Biochem Soc Trans. 2005; 33(Pt 4): 737-742. PubMed Abstract | Publisher Full Text

27. Beck CF: Signaling pathways from the chloroplast to the nucleus. Planta. 2005; 222(5): 743-756.

PubMed Abstract | Publisher Full Text

28. Papenbrock J, Grimm B: Regulatory network of tetrapyrrole biosynthesisstudies of intracellular signaling involved in metabolic and developmental 
control of plastids. Planta. 2001; 213(5): 667-681.

PubMed Abstract | Publisher Full Text

29. Papenbrock J, Mishra S, Mock HP, et al.: Impaired expression of the plastidic ferrochelatase by antisense RNA synthesis leads to a necrotic phenotype of transformed tobacco plants. Plant J. 2001; 28(1): 41-50.

PubMed Abstract | Publisher Full Text

30. Peter E, Grimm B: GUN4 is required for posttranslational control of plant tetrapyrrole biosynthesis. Mol Plant. 2009; 2(6): 1198-1210. PubMed Abstract | Publisher Full Text

31. Formighieri $\mathrm{C}, \mathrm{Ceol} \mathrm{M}$, Bonente $\mathrm{G}$, et al:: Retrograde signaling and photoprotection in a gun4 mutant of Chlamydomonas reinhardtii. Mol Plant. 2012; 5(6): 1242-1262.

PubMed Abstract | Publisher Full Text

32. Gorman DS, Levine RP: Cytochrome $f$ and plastocyanin - their sequence in photosynthetic electron transport chain of Chlamydomonas reinhardi. Proc Natl Acad Sci U S A. 1965; 54(6): 1665-1669.

PubMed Abstract | Publisher Full Text | Free Full Text

33. Sueoka N: Mitotic replication of deoxyribonucleic acid in Chlamydomonas reinhardi. Proc Natl Acad Sci U S A. 1960; 46(1): 83-91. PubMed Abstract | Publisher Full Text | Free Full Text

34. Kindle KL, Schnell RA, Fernandez E, et al:: Stable nuclear transformation of chlamydomonas using the Chlamydomonas gene for nitrate reductase. J Cell Biol. 1989; 109(6 Pt 1): 2589-2601.

PubMed Abstract | Publisher Full Text | Free Full Text

35. Davies JP, Weeks DP, Grossman AR: Expression of the arylsulfatase gene from the beta 2-tubulin promoter in Chlamydomonas reinhardtii. Nucleic Acids Res. 1992; 20(12): 2959-2965.

PubMed Abstract | Publisher Full Text | Free Full Text

36. Smith BM, Morrissey PJ, Guenther JE, et al:: Response of the Photosynthetic Apparatus in Dunaliella salina (Green Algae) to Irradiance Stress. Plant Physiol. 1990; 93(4): 1433-1440.

PubMed Abstract | Publisher Full Text | Free Full Text

37. Laemmli UK: Cleavage of structural proteins during the assembly of the head of bacteriophage T4. Nature. 1970; 227(5259): 680-685. PubMed Abstract | Publisher Full Text

38. Arnon DI: Copper enzymes in isolated chloroplasts. Polyphenoloxidase in Beta vulgaris. Plant Physiol. 1949; 24(1): 1-15. PubMed Abstract | Publisher Full Text | Free Full Text

39. Melis A, Spangfort M, Andersson B: Light-absorption and electron-transport balance between photosystem-II and photosystem-I in spinach-chloroplasts. Photochem Photobiol. 1987; 45(1): 129-136. Publisher Full Text

40. Nott A, Jung HS, Koussevitzky S, et al:: Plastid-to-nucleus retrograde signaling. Ann Rev Plant Biol. 2006; 57: 739-759. PubMed Abstract | Publisher Full Text

41. Johanningmeier U, Howell SH: Regulation of light-harvesting chlorophyllbinding protein mRNA accumulation in Chlamydomonas reinhardi. Possible involvement of chlorophyll synthesis precursors. J Biol Chem. 1984; 259(21)
$13541-13549$

PubMed Abstract

42. Susek RE, Ausubel FM, Chory J: Signal transduction mutants of Arabidopsis uncouple nuclear $C A B$ and $R B C S$ gene expression from chloroplast development. Cell. 1993; 74(5): 787-799. PubMed Abstract | Publisher Full Text

43. Strand A, Asami T, Alonso J, et al:: Chloroplast to nucleus communication triggered by accumulation of Mg-protoporphyrinIX. Nature. 2003; 421(6918): 79-83.

PubMed Abstract | Publisher Full Text

44. Woodson JD, Perez-Ruiz JM, Chory J: Heme synthesis by plastid ferrochelatase I regulates nuclear gene expression in plants. Curr Biol. 2011; 21(10): 897-903.

PubMed Abstract | Publisher Full Text

45. Davison PA, Schubert HL, Reid JD, et al:: Structural and biochemical characterization of Gun4 suggests a mechanism for its role in chlorophyll biosynthesis. Biochemistry. 2005; 44(21): 7603-7612. PubMed Abstract | Publisher Full Text

46. Adhikari ND, Orler R, Chory J, et al.: Porphyrins promote the association of GENOMES UNCOUPLED 4 and a Mg-chelatase subunit with chloroplast membranes. J Biol Chem. 2009; 284(37): 24783-24796. PubMed Abstract | Publisher Full Text | Free Full Text

47. Adhikari ND, Froehlich JE, Strand DD, et al:: GUN4-porphyrin complexes bind the ChIH/GUN5 subunit of Mg-chelatase and promote chlorophyll biosynthesis in Arabidopsis. Plant Cell. 2011; 23(4): 1449-1467. PubMed Abstract | Publisher Full Text | Free Full Text

48. Peter $\mathrm{E}$, Wallner $\mathrm{T}$, Wilde $\mathrm{A}$, et al:: Comparative functional analysis of two hypothetical chloroplast open reading frames (ycf) involved in chlorophyl biosynthesis from Synechocystis sp. PCC6803 and plants. J Plant Physiol. 2011; 168(12): 1380-1386. PubMed Abstract | Publisher Full Text

49. Sobotka R, Dühring U, Komenda J, et al:: Importance of the cyanobacterial Gun4 protein for chlorophyll metabolism and assembly of photosynthetic complexes. J Biol Chem. 2008; 283(38): 25794-25802. PubMed Abstract | Publisher Full Text | Free Full Text

50. Wilde A, Mikolajczyk S, Alawady A, et al.: The gun4 gene is essential for cyanobacterial porphyrin metabolism. FEBS Lett. 2004; 571(1-3): 119-123. PubMed Abstract | Publisher Full Text

51. Larkin RM, Alonso JM, Ecker JR, et al:: GUN4, a regulator of chlorophyll synthesis and intracellular signaling. Science. 2003; 299(5608): 902-906. PubMed Abstract | Publisher Full Text

52. Verdecia MA, Larkin RM, Ferrer JL, et al.: Structure of the Mg-chelatase cofactor GUN4 reveals a novel hand-shaped fold for porphyrin binding. PLOS Biol. 2005; 3(5): e151.

PubMed Abstract | Publisher Full Text | Free Full Text

53. Tanaka R, Tanaka A: Tetrapyrrole biosynthesis in higher plants. Annu Rev Plant Biol. 2007; 58: 321-346.

PubMed Abstract | Publisher Full Text 


\section{Open Peer Review}

\section{Current Peer Review Status:}

\section{Version 1}

Reviewer Report 09 July 2013

https://doi.org/10.5256/f1000research.1698.r1048

(C) $2013 \mathrm{Jin}$ E. This is an open access peer review report distributed under the terms of the Creative Commons Attribution License, which permits unrestricted use, distribution, and reproduction in any medium, provided the original work is properly cited.

\section{EonSeon Jin}

Department of Life Science, College of Natural Science, Hanyang University, Seoul, South Korea

This manuscript presents data regarding phenotype of isolated mutants (6F14), identification of the mutation locus in $6 F 14$ and its complementation. The results revealed that $6 F 14$ is defective in the GUN4 (genome uncoupled 4) gene which regulate MgChel activity. Therefore, the transformation of 6 F14 with a GUN4 gene restored the wild type phenotype with over-expressing the GUN4 protein. The authors concluded that $6 F 14$ is the second gun4 mutant identified in Chlamydomonas. In that sense, the study of 6F14 (gun4 II) is not novel. However, the authors have shown the difference of mutation locus of gun4 I (earlier identified) and gun4 II (in this study) and also the differences of light sensitivity and chlorophyll content which is very interesting. I do have some suggested revisions:

1. If the authors compare all physiological responses for two gun4 mutants and their parental wild types in the same culture condition, it would explain more clearly the differences between the gun4 II and gun4 I mutants.

2. Authors may need to propose the future experiment with this new gun4 mutant (6F14) in the discussion section of the article. 3. I noticed that the introduction part of your abstract (up to 5 lines) is almost identical with your recent paper "Identification and molecular characterization of a novel Chlamydomonas reinhardtii mutant defective in chlorophyll biosynthesis" paper. I would recommend you to revise the introduction part of this abstract.

Competing Interests: No competing interests were disclosed.

I confirm that I have read this submission and believe that I have an appropriate level of expertise to confirm that it is of an acceptable scientific standard.

Reviewer Report 09 July 2013

https://doi.org/10.5256/f1000research.1698.r1047 
(C) 2013 Yokthongwattana K. This is an open access peer review report distributed under the terms of the Creative Commons Attribution License, which permits unrestricted use, distribution, and reproduction in any medium, provided the original work is properly cited.

\section{Kittisak Yokthongwattana}

Department of Biochemistry, Mahidol University, Bangkok, Thailand

This interesting paper by Mitra et al. presents results that show another allele of the gun4 mutant in Chlamydomonas. Although this is not the first article to report on gun4 mutant, it is important as it does provides extra phenotypic studies that show both consistent results and novel investigations. I do have some minor concerns that the authors should consider to improve the manuscript:

1. The title is somewhat misleading as the progressive Chl deficiency is just one of the phenotypes of this mutant; please consider properly revising it.

2. Why did the authors need to put up so many figures in one article? Some of the figures are not really necessary and can be put attached online as supplementary figures. With too many figures, the article can become very boring to read.

3. The authors should put some more emphasis on the interesting findings like the genetic rearrangement of the gun4 gene in the mutant, for example.

4. Unless the authors made further characterization on the two HYP genes regarding their sequences and deduced amino acid and possible functions, they can be omitted from the paper as they would confuse the reader.

Competing Interests: No competing interests were disclosed.

I confirm that I have read this submission and believe that I have an appropriate level of expertise to confirm that it is of an acceptable scientific standard. 
The benefits of publishing with F1000Research:

- Your article is published within days, with no editorial bias

- You can publish traditional articles, null/negative results, case reports, data notes and more

- The peer review process is transparent and collaborative

- Your article is indexed in PubMed after passing peer review

- Dedicated customer support at every stage

For pre-submission enquiries, contact research@f1000.com 